\title{
Antibiotic action revealed by real-time imaging of the mycobacterial membrane
}

Michael G. Wuo¹, Charles L. Dulberger², Robert A. Brown3, Alexander Sturm4, Eveline Ultee5, Zohar Bloom-Ackermann4, Catherine Choi ${ }^{4}$, Ethan C. Garner ${ }^{6}$, Ariane Briegel5, Deborah T. Hung $4,7,8$, Eric J. Rubin², Laura L. Kiessling1*

\section{Affiliations:}

1Department of Chemistry, Massachusetts Institute of Technology, Cambridge, MA o2139, USA

${ }^{2}$ Department of Immunology and Infectious Diseases, Harvard T.H. Chan School of Public Health, Boston 02115, MA, USA

3Department of Biochemistry of Wisconsin-Madison, Madison WI 53706-1544, USA

4Broad Institute of MIT and Harvard, Cambridge, MA 02142, USA

5Institute of Biology, University of Leiden, 2333 BE Leiden, Netherlands

${ }^{6}$ Department of Molecular and Cellular Biology, Harvard University, Cambridge, MA 02138 USA

7Department of Molecular Biology and Center for Computational and Integrative Biology, Massachusetts General Hospital, Boston, MA, USA

${ }^{8}$ Department of Genetics, Harvard Medical School, Boston, MA, USA

*Corresponding author Email: kiesslin@mit.edu

\begin{abstract}
The current understanding of mycobacterial cell envelope remodeling in response to antibiotics is limited. Chemical tools that report on phenotypic changes with minimal cell wall perturbation are critical to gaining insight into this time-dependent phenomenon. Herein we describe a fluorogenic chemical probe that reports on mycobacterial cell envelope assembly in real time. We used time-lapse microscopy to reveal distinct spatial and temporal changes in the mycobacterial membrane upon treatment with frontline antibiotics. Differential antibiotic treatment elicited unique cellular phenotypes, providing a platform for monitoring cell envelope construction and remodeling responses simultaneously. Analysis of the imaging data indicates a role for antibiotic-derived outer membrane vesicles in immune modulation.
\end{abstract}


Mycobacterial cell envelope biogenesis and remodeling are dynamic processes critical to infectivity and recalcitrance to antibiotics(1). Mycolyl arabinogalactan (mAG) is the principal constituent of the cellular envelope and acts as a physical barrier between the bacillus and its environment(2-4). Changes in envelope architecture play a critical role in colony morphology, pellicle formation, and drug resistance (5-7). Substantial restructuring of the cell envelope as a result of increased production of mycolic acids, changes in arabinogalactan synthesis, and modifications of peptidoglycan crosslinks have been reported to contribute to mechanisms of bacterial persistence and cellular survival(8-11). Previous studies have evaluated morphological changes in physical dimensions and DNA compaction after antibiotic treatment (Fig 1A) (12). However, these changes alone cannot account for the persistent infections that reestablish following antibiotic treatment. New approaches to evaluate mycobacterial membrane remodeling dynamics under antibiotic stress stand to identify mechanisms of mycobacterial persistence and discover new therapeutic strategies to address the growing threat of mycobacterial antibiotic resistance.

Most frontline antibiotics engage biosynthetic enzymes involved in mycobacterial cell envelope construction. Strategies that report in real-time on mycomembrane dynamics can illuminate how mycobacterial growth, division, and remodeling relate to survival advantages in the bacillus. We recently described a fluorogenic probe, quencher trehalose fluorophore (QTF)(13), that reports on the growth of the lipid-rich mycobacterial cell envelope (Fig. 1A). To improve the thermodynamic and hydrolytic stability of the probe, we made a single atom substitution at the trehalose C6-position to generate an amide-containing derivative, $\mathrm{N}$ quencher trehalose fluorophore or N-QTF (Fig. 1B, Supp. Fig. S1, S2). We demonstrate that NQTF activation in mycobacterial species is mediated by mycolyltransferases $\mathrm{Ag} 85 \mathrm{~A}-\mathrm{C}$, and this probe localizes to the polar and septal regions (Fig. 1C. Supp Fig. S3) of growing mycobacteria as previously described for QTF. Thus, N-QTF enables selective, real-time visualization of envelope biogenesis. 
We leveraged N-QTF to examine spatial and temporal fluorogenic phenotypes in response to antibiotic stress. We first determined how antibiotic treatment influenced fluorescence resulting from N-QTF processing. Using a time-course fluorescence assay, we subjected Mycobacterium smegmatis (Msmeg) to frontline Mycobacterium tuberculosis (Mtb) antibiotics ethambutol (EMB), rifampicin (RIF), and isoniazid (INH) at $12.5 \mu \mathrm{g} / \mathrm{mL}$ (low, sub-MIC) and $50 \mu \mathrm{g} / \mathrm{mL}$ (high, super-MIC) concentrations. The bulk fluorescence measured over six hours (two doubling times, Supp Fig. S4) tracked with antibiotic concentration with a higher fluorescent signal at higher antibiotic concentration (Fig. 1D). A linear correlation of fluorescence and OD600 was observed for all treatment conditions, suggesting that the bacteria could grow and multiply under the assay conditions during this short, early period of observation (Supp. Fig. S4). Of the frontline antibiotics, ethambutol (EMB)-treated cells exhibited the largest fluorescence increase at high concentrations and largest fluorescence decrease at low concentrations relative to untreated control. Rifampicin (RIF)-treated cells had the smallest relative fluorescence change, while isoniazid (INH) treatment had an intermediate response. These data suggest Msmeg increases lipid remodeling activity under antibiotic stress and that each anti-mycobacterial agent elicits a distinct cell membrane response.

EMB inhibits the arabinosyltransferases EmbA-C(14). These enzymes generate the cell envelope arabinan layer, to which the lipid-rich mycolic acid layer is appended. Prior studies indicate ethambutol treatment results in an intracellular accumulation and secretion of trehalose mycolates and mycolic acids in the culture media $(15,16)$. In one study, EMB treatment induced increased expression of the polar scaffolding protein DivIVA(17), a fulcrum for the organization of the polar elongation complex, elongasome. This investigation recorded active growth at the cellular poles; paradoxically, the level of mycolic acid at the cellular poles appeared to be reduced (17). We reasoned that these counterintuitive results likely stem from the non-specific fluorescent dye used to monitor mycolic acid changes. The fluorescence of such dyes depends on the hydrophobicity of the region; therefore, they cannot report on dynamic 
remodeling. We postulated that $\mathrm{N}-\mathrm{QTF}$ could report on lipid restructuring in real time. Using time-lapse imaging under microfluidic control, we continuously supplied N-QTF to Msmeg and flowed either vehicle or EMB antibiotic $(10 \mu \mathrm{g} / \mathrm{mL})$ into the culture chamber at defined time points (Fig. 2A-C, Movies S1-S4). Changes in fluorescence localization were monitored over time. After one doubling time, EMB-treated Msmeg showed bright fluorescence localization to the bacillus' polar regions. The observed phenotype increased over time, and after 16 hours, we detected ejection of the mycomembrane lipids at these sites. These data suggest that the cell pole is more fluid than previously described, a property that explains why non-specific fluorescent dyes could not report on the lipid changes revealed by N-QTF. These new findings underscore the importance of capturing the dynamics of lipid remodeling under antibiotic treatment, as spatiotemporal resolution provides mechanistic insight into changes in cell wall biosynthetic pathways.

We reasoned that other cell wall biosynthesis inhibitors might exhibit similar lipid localization phenotypes. The bactericidal frontline antibiotic INH targets the enoyl reductase InhA involved in cell envelope construction and perturbs the available mycolic acid lipid pool. Time-lapse imaging revealed a delayed fluorogenic phenotype after one doubling time (Fig 2D). The fluorescence appeared to be dispersed throughout the cell membrane, supporting the known lytic mechanism of action of INH at a super-MIC concentration(18). Cell surface blebbing followed by membrane shredding has been reported to precede lytic activity in INH-treated Msmeg(19). Unexpectedly, we observed that EMB and INH, which both target cell envelope biosynthesis, did not produce similar phenotypes, suggesting differential drug mechanism of action results in altered lipid localization phenotypes in mycobacterial membranes.

We next tested whether antibiotics that block processes that do not directly impact cell envelope biogenesis would afford mycomembrane perturbations. To this end, we treated Msmeg with RIF, an antibiotic that engages bacterial RNA polymerase and blocks the initiation of RNA synthesis. Time-lapse imaging revealed the RIF treatment promoted the appearance of outer 
membrane vesicles (OMVs) (Fig. 2E). This phenotype was absent in either EMB- and INHtreated samples, indicating a RIF-specific stress response. Bacteria, including $M t b$, actively release outer membrane vesicles in the absence of stress(2O-22); however, enhanced OMV production following antibiotic treatment had not been previously observed. Imaging of N-QTF in RIF treated cells reveals previously uncharacterized cell wall activity upon inhibition of bacterial transcription.

To gather additional insight into the varied antibiotic phenotypes observed in fluorescence microscopy, we used cryo-transmission electron microscopy (cryo-TEM). Guided by our dynamic phenotypic profiling, we treated Msmeg with EMB, INH, or RIF at sublethal doses. After four hours of antibiotic treatment, cryo-TEM images revealed dramatic differences, analogous to those observed in time-lapse microscopy (Fig. 2F). EMB-treated bacteria showed lipid droplet accumulation at the cell poles. INH treatment caused lipid accumulation along the cell length and polar regions. RIF exposure resulted in the appearance of phosphate and lipidrich subcellular bodies(23) appearing throughout the bacillus, suggesting a priming step that occurs before OMV release. These data indicate that N-QTF does not itself contribute to the observed phenotypes but strictly acts as a reporter of cell remodeling.

The distinct OMV phenotype observed in RIF-treated mycobacteria was intriguing, as cryoTEM could not capture this time-dependent phenotype, and previous studies indicate that secreted mycobacterial OMVs can modulate host immunity through TLR agonism. In this way, OMVs can help Mtb subvert immune surveillance by macrophages(2O). We posited that the OMV phenotype observed in RIF-treated mycobacteria might provide insight into the recent rise in $M t b$ resistance to RIF. Indeed, RIF-treated infected macrophages can give rise to RIFresistant $M t b$ with modified lipid envelopes (24). To query how mycobacterial OMVs under antibiotic treatment modulate host immune response, we isolated OMVs from the supernatant of DMSO vehicle- or RIF-treated $M t b$ and used them to stimulate human blood monocytederived macrophages (Fig. 3A). We compared the responses to that of lipopolysaccharide from 
Gram-negative Escherichia coli, a potent stimulant of the human immune system. RT-qPCR analysis of primary human macrophages incubated with OMVs from DMSO-treated Mtb afforded an increase in the expression of primary proinflammatory cytokines. Notably, treatment of primary human macrophages with OMVs from RIF-treated $M t b$ decreased proinflammatory cytokine expression relative to OMVs from vehicle-treated Mtb. To further explore how a range of frontline antibiotics influence OMV-mediated immune modulation, we isolated OMVs from EMB-treated $M t b$. The proinflammatory cytokine response from EMB OMVs was similar to that of the DMSO OMV control across the proinflammatory cytokines IL1b, IL-6, and IL12b (Fig 3C). These data indicate that the distinct phenotypes observed in our imaging studies have different consequences on immune activation. The data suggest that cell envelope remodeling by Mtb in response to RIF treatment can help evade host defense.

OMVs help $M t b$ and other bacteria deliver biomolecules at a high effective concentration. To explore the molecular basis of macrophage modulation by antibiotic-treated OMVs, we performed a targeted metabolomics analysis of 167 metabolites (Fig. 3D)(25). The data indicated a significant upregulation in adenosine pathway metabolites in RIF OMVs over DMSO OMVs. The largest fold-change was observed for cyclic AMP (cAMP), suggesting a link between intramembrane vesicle cyclic AMP concentration and immune modulation. Since EMB OMVs did not significantly activate the proinflammatory macrophage response, we hypothesized that cAMP would not be present in EMB OMV metabolites. Consistent with this hypothesis, a targeted metabolomics analysis of EMB OMVs showed no increase in cAMP or other adenosine metabolites (Fig. 3D). Changes in intramacrophage cAMP levels have been observed in $M t b$ infection. Increases in cAMP can dampen macrophage signaling through protein kinase A and the cAMP response-element binding protein pathways(26-28); however, cAMP's presence in OMVs had not been examined. The delivery of high local concentrations of encapsulated cAMP in response to RIF may allow $M t b$ to control host macrophage immune responses, suggesting a mechanism for bacterial survival and subsequent host tolerance. 
The mycobacterial membrane grants $M t b$ recalcitrance to antimicrobials. How the mycomembrane dynamically remodels in response to antibiotic stress was poorly understood. By leveraging a substrate mimic of the enzymes that control mycomembrane remodeling, we investigated changes in membrane phenotypes from frontline antibiotic treatment without genetic manipulation. The critical observation that the spatial and temporal localization of the lipids is dependent on an antibiotic's mechanism of action highlights the utility of our approach. The secretion of OMVs from RIF-treated mycobacteria was unprecedented and suggests bacteria modulate the host immune environment as collateral damage to their stress response (Supp. Fig. S5). Our findings indicate that consideration of the consequences of bacterial treatment on host immune responses could yield more effective strategies for antibiotic targeting of $M t b$. Last, we demonstrate how the mycomembrane can be leveraged to report on the biology of existing antibiotics and discover new mechanisms of action. 


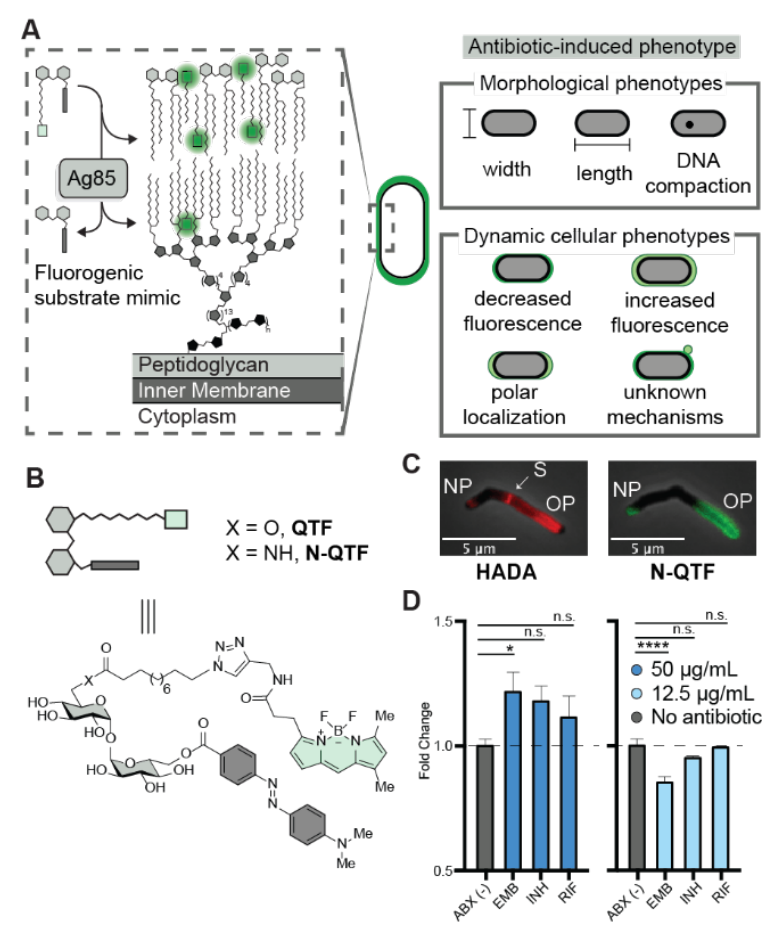

Figure 1. Analysis of N-QTF, a fluorogenic, real-time reporter of mycolyltransferase activity. (A) The fluorogenic substrate (QTF or N-QTF, B) is activated by the Ag85 enzyme complex and serves as a reporter of dynamic antibiotic-induced cellular phenotypes. (B) The fluorogenic probes, QTF and N-QTF, mimic critical features of trehalose monomycolate, the natural substrate of Ag85. (C) Fluorescence labeling of $M$. smegmatis with HADA (left) or N-QTF (right). NP: new pole OP: old pole S: septum (D) Bulk fluorescence measurements show concentration-dependent N-QTF activation differences upon treatment with frontline antibiotics at $50 \mu \mathrm{g} / \mathrm{mL}$ (left, blue) and $12.5 \mu \mathrm{g} / \mathrm{mL}$ (right, light blue). (Ordinary onewayANOVA ${ }^{* * *} \mathrm{p} \leq 0.0001,{ }^{* * *} \mathrm{p} \leq 0.001,{ }^{* *} \mathrm{p} \leq 0.01,{ }^{*} \mathrm{p} \leq 0.05$ and non-significant $\left.>0.05\right)$. Data shown are the average of triplicate samples \pm SEM in triplicate and representative of two independent experiments. 
bioRxiv preprint doi: https://doi.org/10.1101/2022.01.07.475452; this version posted January 9,2022 . The copyright holder for this preprint

A

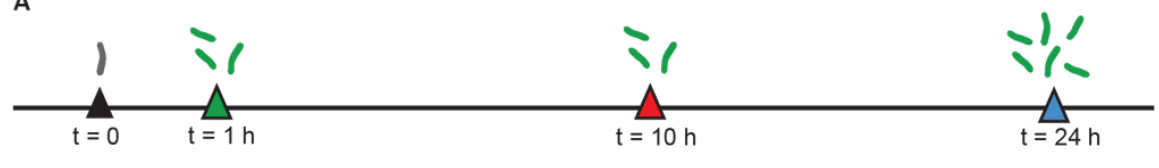

B


C

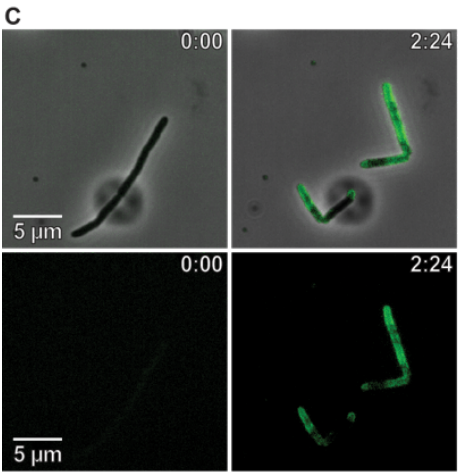

Ethambutol

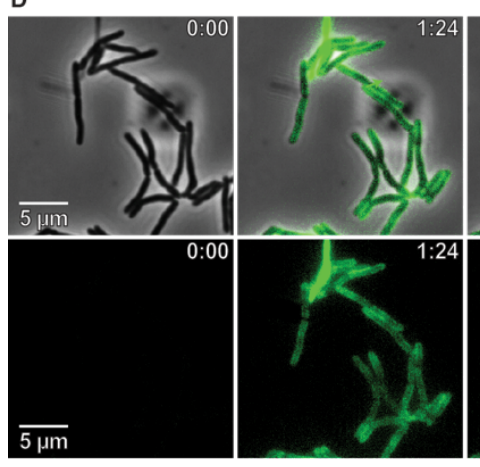

Isoniazid
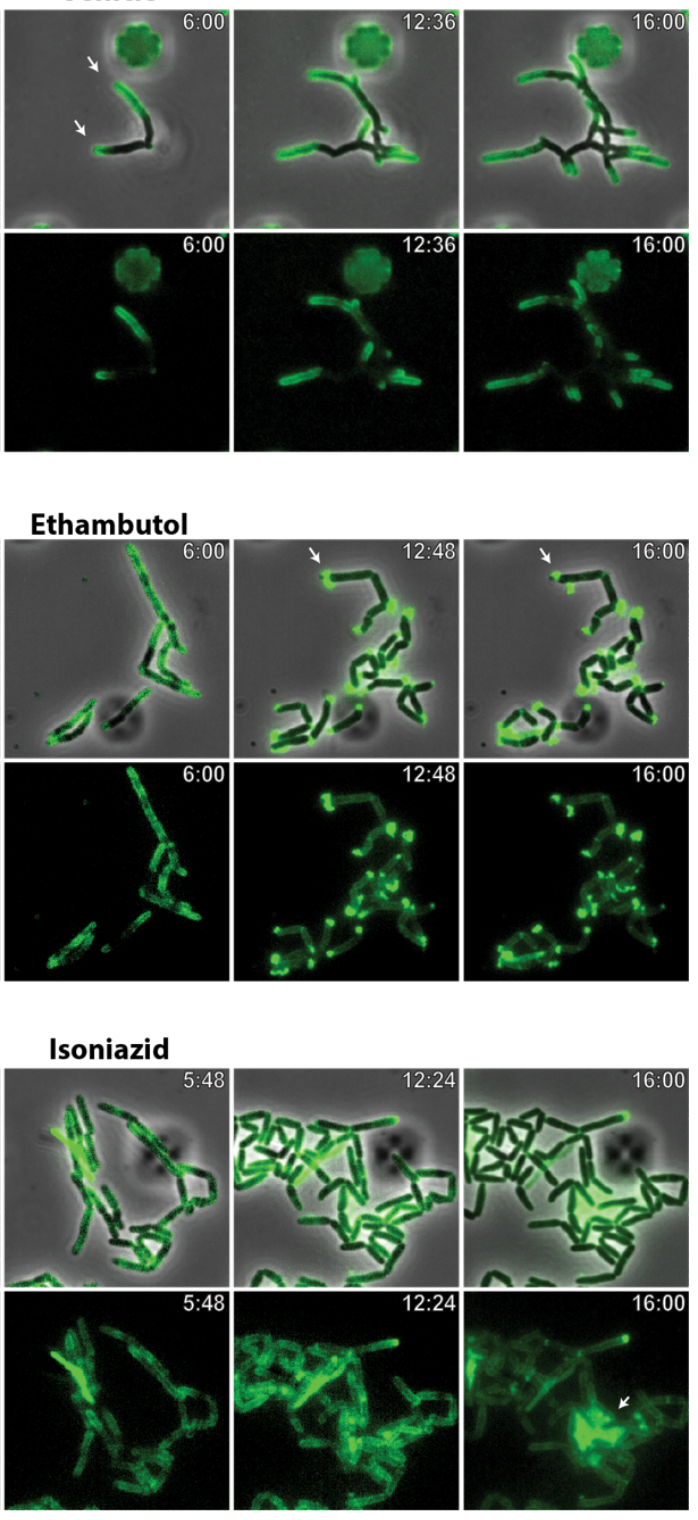

M. smegmatis culture (no probe) $\Delta \mathrm{N}$-QTF addition

$\Delta \mathrm{Abx}$ and $\mathrm{N}-\mathrm{QTF}$ addition

$\triangle$ Endpoint fluorescence

$F$

$\mathrm{N}-\mathrm{QTF}$ only (no antibiotic)



Ethambutol (Arabinan)

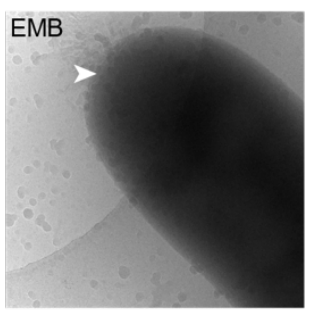

Isoniazid (Mycolic Acids)
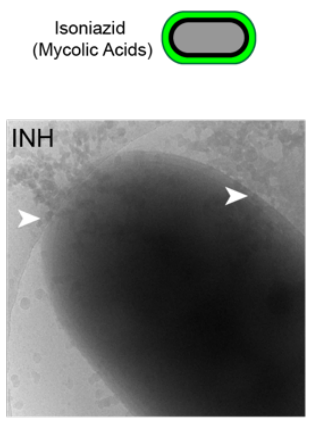

E

Rifampicin
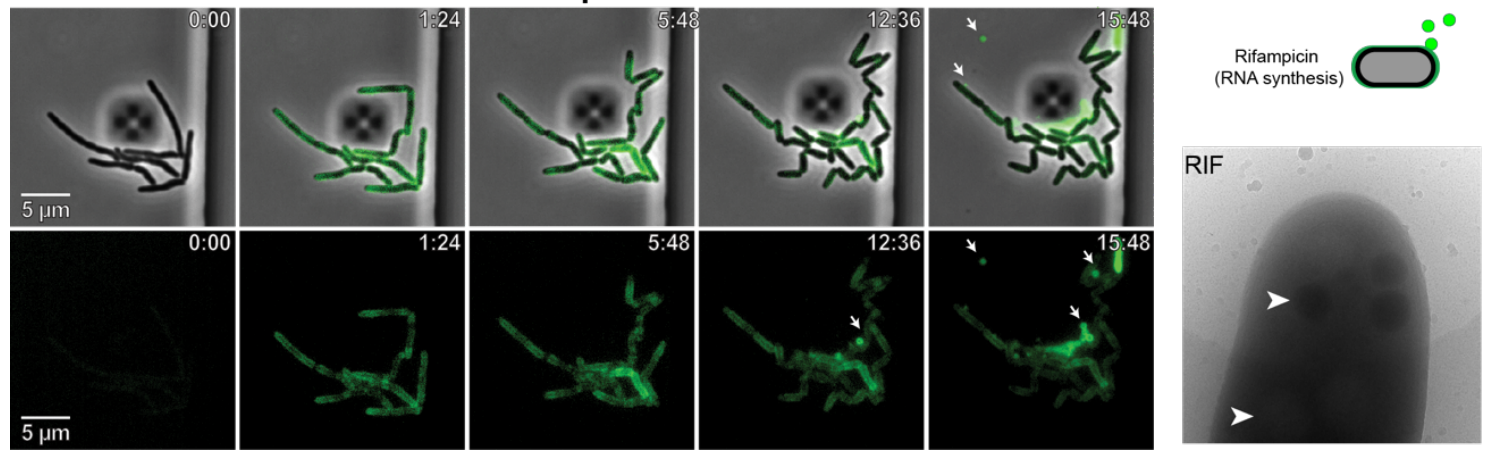
Figure 2. Antibiotic-specific phenotypes from fluorescence and superimposed phase imaging of Msmeg. (A) N-QTF and antibiotic treatment timeline used to monitor antibiotic phenotypes. (B) Combined microfluidics and time-lapse microscopy were used to assess antibiotic phenotypes relative to vehicle control following (C) EMB treatment, (D) INH treatment, (E) RIF-treatment. (F) Cryo-transmission electron microscopy after four hours of exposure. Arrows indicate antibiotic phenotypes. Images are presented for vehicle, or treatment with EMB, INH, or RIF. Data are representative of two individual experiments. 
A
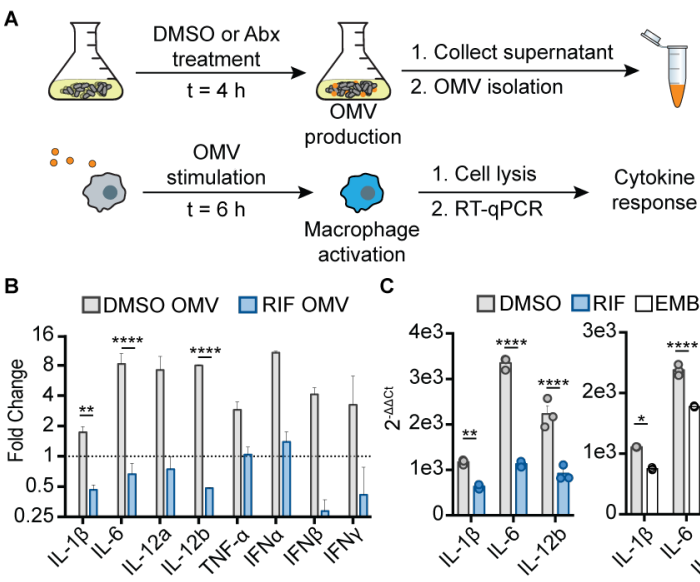

C $\quad$ DMSO $\square$ RIF $\square$ EMB
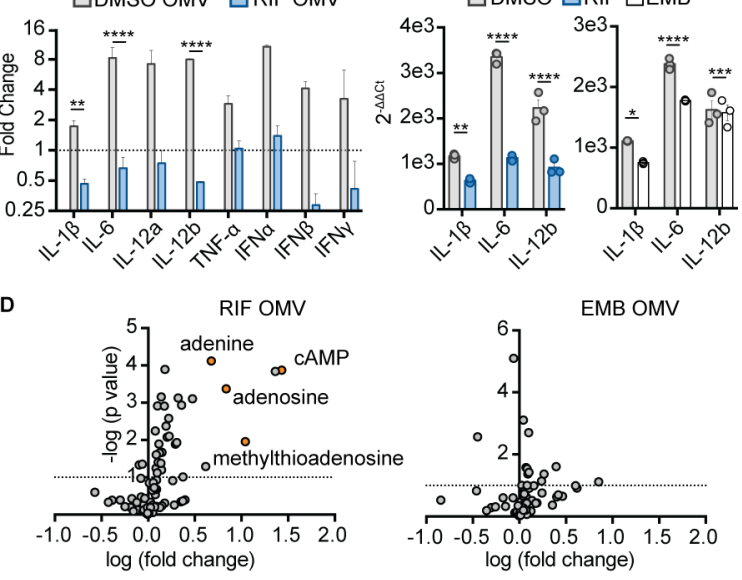

Figure 3. Assessment of human macrophage responses to OMVs from $M t b$. (A) Schematic depiction of experimental workflow. OMVs were isolated from $M t b$ following treatment with DMSO, RIF, or EMB and exposed to human macrophages. Cytokine expression was measured following macrophage stimulation with purified OMVs. (B) RT-qPCR analysis of macrophage cytokine expression in response to RIF OMVs relative to LPS control. (C) A comparison of macrophage cytokine expression elicited by RIF OMVs compared to that from EMB OMVs. (Two-way ANOVA **** $\leq 0.0001,{ }^{* * *} \mathrm{p} \leq 0.001,{ }^{* *} \mathrm{p} \leq 0.01,{ }^{*} \mathrm{p} \leq 0.05$ and non-significant $>0.05$ ). (D) Untargeted metabolomics of polar metabolites present in OMVs from RIF- or EMBtreated $M t b$. Data are representative of two independent experiments. 


\section{References}

1. C. L. Dulberger, E. J. Rubin, C. C. Boutte, The mycobacterial cell envelope - a moving target. Nat. Rev. Microbiol. 18, 47-59 (2020).

2. M. Jankute, J. A. G. Cox, J. Harrison, G. S. Besra, Assembly of the Mycobacterial Cell Wall. Annu. Rev. Microbiol. 69, 405-423 (2015).

3. P. J. Brennan, Structure, function, and biogenesis of the cell wall of Mycobacterium tuberculosis. Tuberc. Edinb. Scotl. 83, 91-97 (2003).

4. G. S. Besra, K. H. Khoo, M. R. McNeil, A. Dell, H. R. Morris, P. J. Brennan, A new interpretation of the structure of the mycolyl-arabinogalactan complex of Mycobacterium tuberculosis as revealed through characterization of oligoglycosylalditol fragments by fastatom bombardment mass spectrometry and $1 \mathrm{H}$ nuclear magnetic resonance spectroscopy. Biochemistry. 34, 4257-4266 (1995).

5. J. Liu, C. E. Barry, G. S. Besra, H. Nikaido, Mycolic acid structure determines the fluidity of the mycobacterial cell wall. J. Biol. Chem. 271, 29545-29551 (1996).

6. A. Venugopal, R. Bryk, S. Shi, K. Rhee, P. Rath, D. Schnappinger, S. Ehrt, C. Nathan, Virulence of Mycobacterium tuberculosis depends on lipoamide dehydrogenase, a member of three multienzyme complexes. Cell Host Microbe. 9, 21-31 (2011).

7. J. M. Chen, G. J. German, D. C. Alexander, H. Ren, T. Tan, J. Liu, Roles of Lsr2 in colony morphology and biofilm formation of Mycobacterium smegmatis. J. Bacteriol. 188, 633641 (2006).

8. K. J. Kieser, E. J. Rubin, How sisters grow apart: mycobacterial growth and division. Nat. Rev. Microbiol. 12, 550-562 (2014).

9. S. Bhamidi, L. Shi, D. Chatterjee, J. T. Belisle, D. C. Crick, M. R. McNeil, A bioanalytical method to determine the cell wall composition of Mycobacterium tuberculosis grown in vivo. Anal. Biochem. 421, 240-249 (2012).

10. M. Jain, C. J. Petzold, M. W. Schelle, M. D. Leavell, J. D. Mougous, C. R. Bertozzi, J. A. Leary, J. S. Cox, Lipidomics reveals control of Mycobacterium tuberculosis virulence lipids via metabolic coupling. Proc. Natl. Acad. Sci. U. S. A. 104, 5133-5138 (2007).

11. A. A. Pohane, C. R. Carr, J. Garhyan, B. M. Swarts, M. S. Siegrist, Trehalose Recycling Promotes Energy-Efficient Biosynthesis of the Mycobacterial Cell Envelope. mBio. 12 (2021), doi:10.1128/mBio.02801-20.

12. T. C. Smith, K. M. Pullen, M. C. Olson, M. E. McNellis, I. Richardson, S. Hu, J. LarkinsFord, X. Wang, J. S. Freundlich, D. M. Ando, B. B. Aldridge, Morphological profiling of tubercle bacilli identifies drug pathways of action. Proc. Natl. Acad.Sci. U.S. A. 117, 18744-18753 (2020).

13. H. L. Hodges, R. A. Brown, J. A. Crooks, D. B. Weibel, L. L. Kiessling, Imaging mycobacterial growth and division with a fluorogenic probe. Proc. Natl. Acad. Sci. U. S. A. 115, 5271-5276 (2018). 
14. L. Zhang, Y. Zhao, Y. Gao, L. Wu, R. Gao, Q. Zhang, Y. Wang, C. Wu, F. Wu, S. S. Gurcha, N. Veerapen, S. M. Batt, W. Zhao, L. Qin, X. Yang, M. Wang, Y. Zhu, B. Zhang, L. Bi, X. Zhang, H. Yang, L. W. Guddat, W. Xu, Q. Wang, J. Li, G. S. Besra, Z. Rao, Structures of cell wall arabinosyltransferases with the anti-tuberculosis drug ethambutol. Science. $\mathbf{3 6 8}$, 1211-1219 (2020).

15. J. O. Kilburn, K. Takayama, Effects of ethambutol on accumulation and secretion of trehalose mycolates and free mycolic acid in Mycobacterium smegmatis. Antimicrob. Agents Chemother. 2o, 401-404 (1981).

16. K. Mikusová, R. A. Slayden, G. S. Besra, P. J. Brennan, Biogenesis of the mycobacterial cell wall and the site of action of ethambutol. Antimicrob. Agents Chemother. 39, 2484-2489 (1995).

17. K. Schubert, B. Sieger, F. Meyer, G. Giacomelli, K. Böhm, A. Rieblinger, L. Lindenthal, N. Sachs, G. Wanner, M. Bramkamp, The Antituberculosis Drug Ethambutol Selectively Blocks Apical Growth in CMN Group Bacteria. mBio. 8, e02213-16.

18. M. Elitas, Isoniazid Killing of Mycobacterium smegmatis NADH Pyrophosphatase Mutant at Single-Cell Level using Microfluidics and Time-Lapse Microscopy. Sci. Rep. 7, 10770 (2017).

19. C. Vilchèze, H. R. Morbidoni, T. R. Weisbrod, H. Iwamoto, M. Kuo, J. C. Sacchettini, W. R. Jacobs, Inactivation of the inhA-encoded fatty acid synthase II (FASII) enoyl-acyl carrier protein reductase induces accumulation of the FASI end products and cell lysis of Mycobacterium smegmatis. J. Bacteriol. 182, 4059-4067 (2000).

20. R. Prados-Rosales, A. Baena, L. R. Martinez, J. Luque-Garcia, R. Kalscheuer, U. Veeraraghavan, C. Camara, J. D. Nosanchuk, G. S. Besra, B. Chen, J. Jimenez, A. GlatmanFreedman, W. R. Jacobs, S. A. Porcelli, A. Casadevall, Mycobacteria release active membrane vesicles that modulate immune responses in a TLR2-dependent manner in mice. J. Clin. Invest. 121, 1471-1483 (2011).

21. T. Nagakubo, N. Nomura, M. Toyofuku, Cracking Open Bacterial Membrane Vesicles. Front. Microbiol. 10, 3026 (2020).

22. M. Toyofuku, N. Nomura, L. Eberl, Types and origins of bacterial membrane vesicles. Nat. Rev. Microbiol. 17, 13-24 (2019).

23. L. R. Comolli, M. Kundmann, K. H. Downing, Characterization of intact subcellular bodies in whole bacteria by cryo-electron tomography and spectroscopic imaging. J. Microsc.

223, 40-52 (2006).

24. C. Genestet, E. Hodille, A. Barbry, J.-L. Berland, J. Hoffmann, E. Westeel, F. Bastian, M. Guichardant, S. Venner, G. Lina, C. Ginevra, F. Ader, S. Goutelle, O. Dumitrescu, Rifampicin exposure reveals within-host Mycobacterium tuberculosis diversity in patients with delayed culture conversion. PLOS Pathog. 17, e1009643 (2021).

25. C. Williams, M. Palviainen, N.-C. Reichardt, P. R.-M. Siljander, J. M. Falcón-Pérez, Metabolomics Applied to the Study of Extracellular Vesicles. Metabolites. 9, 276 (2019). 
26. N. Agarwal, G. Lamichhane, R. Gupta, S. Nolan, W. R. Bishai, Cyclic AMP intoxication of macrophages by a Mycobacterium tuberculosis adenylate cyclase. Nature . 460, 98-102 (2009).

27. G. Bai, G. S. Knapp, K. A. McDonough, Cyclic AMP signalling in mycobacteria: redirecting the conversation with a common currency. Cell. Microbiol. 13, 349-358 (2011).

28. Y. Chung, V. Pasquinelli, J. O. Jurado, X. Wang, N. Yi, P. F. Barnes, V. E. Garcia, B. Samten, Elevated Cyclic AMP Inhibits Mycobacterium tuberculosis-Stimulated T-cell IFNY Secretion Through Type I Protein Kinase A. J. Infect. Dis. 217, 1821-1831 (2018).

29. K. Birsoy, T. Wang, W. W. Chen, E. Freinkman, M. Abu-Remaileh, D. M. Sabatini, An Essential Role of the Mitochondrial Electron Transport Chain in Cell Proliferation Is to Enable Aspartate Synthesis. Cell. 162, 540-551 (2015).

30. D. H. Anderson, G. Harth, M. A. Horwitz, D. Eisenberg, An interfacial mechanism and a class of inhibitors inferred from two crystal structures of the Mycobacterium tuberculosis $30 \mathrm{kDa}$ major secretory protein (Antigen $85 \mathrm{~B}$ ), a mycolyl transferase. J. Mol. Biol. 307, 671-681 (2001).

31. L. Favrot, A. E. Grzegorzewicz, D. H. Lajiness, R. K. Marvin, J. Boucau, D. Isailovic, M. Jackson, D. R. Ronning, Mechanism of inhibition of Mycobacterium tuberculosis antigen 85 by ebselen. Nat. Commun. 4, 2748 (2013). 


\section{Supplementary Materials for}

\section{Antibiotic action revealed by real-time imaging of the mycobacterial membrane}

Michael G. Wuo ${ }^{1}$, Charles L. Dulberger ${ }^{2}$, Robert A. Brown³, Alexander Sturm4 ${ }^{4}$ Eveline Ultee5, Zohar Bloom-Ackermann, Catherine Choi ${ }^{4}$, Ethan C. Garner6, Ariane Briegel5, Deborah T. Hung $4,7,8$, Eric J. Rubin², Laura L. Kiessling ${ }^{1 *}$

\section{Affiliations:}

${ }^{1}$ Department of Chemistry, Massachusetts Institute of Technology, Cambridge, MA 02139, USA

2Department of Immunology and Infectious Diseases, Harvard T.H. Chan School of Public Health, Boston 02115, MA, USA

3Department of Biochemistry of Wisconsin-Madison, Madison WI 53706-1544, USA

4Broad Institute of MIT and Harvard, Cambridge, MA 02142, USA

5Institute of Biology, University of Leiden, 2333 BE Leiden, Netherlands

${ }^{6}$ Department of Molecular and Cellular Biology, Harvard University, Cambridge, MA 02138 USA

7Department of Molecular Biology and Center for Computational and Integrative Biology, Massachusetts General Hospital, Boston, MA, USA

8Department of Genetics, Harvard Medical School, Boston, MA, USA

*Corresponding author. Email: kiesslin@mit.edu

\section{This PDF file includes:}

Materials and Methods

Supplementary Text

Figs. S1 to S5

Tables $\mathrm{S} 1$ to $\mathrm{S} 2$

Captions for Movies S1 to S4

References 


\section{Materials and Methods}

\section{General Information for Synthetic Methods and Materials}

All reagents for synthetic starting materials, buffers, and antibiotics were used as received from commercial manufacturers, unless otherwise noted. Organic solvents were purified according to published method guidelines (1). Water was purified using a Millipore Milli-Q Integral Water Purification system. All reactions were conducted under an intert nitrogen atmosphere in oven dried glassware unless otherwise stated. Analytical thin layer chromatography (TLC) was carried out on E. Merck (Darmstadt) TLC plates pre-coated with silica gel 60 F254 (250 $\mu$ m layer thickness). Analyte visualization was accomplished using a UV lamp or by charring with phosphomolybdic acid solution. Flash column chromatography was performed with Silicycle flash silica gel (40-63 $\mu \mathrm{m}, 60 \AA$ pore size) using the quoted eluent. $1 \mathrm{H}$ and $13 \mathrm{C}$ nuclear magnetic resonance (NMR) spectra were recorded on a $400 \mathrm{MHz}$ spectrometer (acquired at $400 \mathrm{MHz}$ for $1 \mathrm{H}$ NMR and $101 \mathrm{MHz}$ for $13 \mathrm{C} \mathrm{NMR}$ ), or a $500 \mathrm{MHz}$ spectrometer (acquired at $500 \mathrm{MHz}$ for $1 \mathrm{H}$ NMR and $126 \mathrm{MHz}$ for $13 \mathrm{C}$ NMR). NMR chemical shifts are reported as follows: chemical shift $(\delta \mathrm{ppm})$, multiplicity $(\mathrm{s}=$ singlet, $\mathrm{d}=$ doublet, $\mathrm{t}=$ triplet, $\mathrm{q}=$ quartet, $\mathrm{p}$ = quintet, or some combination thereof. Chemical shifts are reported relative to residual solvent peaks in parts per million $\left(\mathrm{CDCl}_{3}\right.$ : $1 \mathrm{H}, 7.27,13 \mathrm{C}, 77.23$; $\left.\mathrm{CD} 3 \mathrm{OD}: 1 \mathrm{H}, 3.31,13 \mathrm{C}, 49.15\right)$. Coupling constants $(\mathrm{J})$ are reported in Hertz $(\mathrm{Hz})$ and rounded to the nearest $0.1 \mathrm{~Hz}$. High-resolution mass spectra (HRMS) were obtained on an electrospray ionization-time of flight (ESI-TOF) Micromass LCT mass spectrometer.

\section{Bacterial strain selection and culture conditions}

Mycobacterial species $M$. smegmatis mc2155, M. marinum BAA-535, and M. tuberculosis H37Rv were grown with shaking at $37^{\circ} \mathrm{C}$ in Middlebrook $7 \mathrm{H} 9$ broth (BD, Franklin Lake, NJ) with $0.2 \%$ (v/v) glycerol, $0.05 \%$ (v/v) Tween-80 with or without OADC supplement (Sigma-Aldrich).

\section{Time-dependent fluorescence assays}

Mycobacterial species $M$. smegmatis mc2155, M. marinum BAA-535, and M. tuberculosis H37Rv were grown to $\mathrm{OD} 600=1$. Strains were diluted to $\mathrm{OD} 600=0.2$. Reactions were initiated by the addition of NQTF to a final volume of $50 \mu \mathrm{L}$ per well $(\mathrm{n}=3)$. Relative fluorescence units were measured at ex/em $485 / 525$ and read every 15 minutes for two doubling times ( $\mathrm{t}=6$ hours) at $37^{\circ} \mathrm{C}$.

\section{Purification of $M . t b$ Ag85 mycolyltransferases}

$M t b$ Ag85A, Ag85B, and Ag85C were obtained through BEI Resources, NIAID, NIH: Purified native protein from $M . t b$. H37Rv antigen 85A (fbpA, Rv3804c, cat. No: NR-14856), antigen $85 \mathrm{~B}$ (fbpB, Rv1886c, cat. No: NR-14857), and antigen 85C (fbpD, Rv3803, cat no: NR-14858). Upon receipt, lyophilized native Ag85 proteins were thawed and suspended in aqueous 1xPBS buffer (Gibco cat no: 10010023$)$ to a concentration of $10 \mu \mathrm{M}$ for storage at $-20{ }^{\circ} \mathrm{C}$. M. tb. Ag85A-C proteins were thawed and used as needed.

\section{Kinetic assays with $M$. tb. Ag85A-C mycolyltransferases}

A flat, clear bottom 96-well black polystyrene microplate (Greiner, cat no: 655097) was used to measure time-dependent N-QTF activation with $5 \mu \mathrm{M}$ N-QTF with a fixed concentration $(1 \mu \mathrm{M})$ of each Ag85 isoform in 1x PBS pH 7.4. Reactions were initiated by the addition of N-QTF to a final volume of $50 \mu \mathrm{L}$ per well $(n=3)$. Relative fluorescence units were measured at ex/em 485/525 and read every 30 seconds for one hour at $37^{\circ} \mathrm{C}$.

\section{Fluorescence microscopy}

Mycobacterial species M. smegmatis mc2155, M. marinum BAA-535, and M. tuberculosis H37Rv were grown to $\mathrm{OD} 600=1$ in either Middlebrook $7 \mathrm{H} 9$ or $7 \mathrm{H} 9+\mathrm{OADC}$ supplement $0.2 \%$ glycerol, $0.05 \%$

Tween-80. Strains were diluted to OD600 $=0.2$ and N-QTF was added at final concentration $2.5 \mathrm{uM}$ in 1 $\mathrm{mL}$ of liquid culture. $10 \mathrm{uL}$ of culture was removed after 24 hours and placed on a glass microscope slide with polylysine-coated cover slips. Slips were sealed and imaged on a Cell Discoverer7 at 100x 
bioRxiv preprint doi: https://doi.org/10.1101/2022.01.07.475452; this version posted January 9,2022 . The copyright holder for this preprint (which was not certified by peer review) is the author/funder, who has granted bioRxiv a license to display the preprint in perpetuity. It is made available under aCC-BY-NC-ND 4.0 International license.

magnification. Visualization of N-QTF was performed and monitored at ex/em 488/525 nm. Imaging processing was performed using ImageJ FIJI software. 


\section{Antibiotic-dependent N-QTF incorporation}

A flat, clear bottom 96-well black polystyrene microplate (Greiner, cat no: 655097) was used to measure time-dependent N-QTF $(1 \mu \mathrm{M})$ activation with frontline antibiotic treatment to $M$. smegmatis mc2155. $\mathrm{EMB}, \mathrm{INH}$, or RIF was used to treat $M$. smegmatis at $\mathrm{OD} 600=0.2$ at either $50 \mu \mathrm{g} / \mathrm{mL}$ or $12.5 \mu \mathrm{g} / \mathrm{mL}$ $(n=3)$. Relative fluorescence units were measured at ex/em $485 / 525$ and read every 15 minutes for two doubling times ( $\mathrm{t}=6$ hours) at $37^{\circ} \mathrm{C}$.

\section{Timelapse microscopy}

M. smegmatis were grown to mid-log and diluted to OD600 of 0.3. Cells were loaded into a CellASIC (cat no: B04A) plate under constant microfluidic flow with $7 \mathrm{H} 9$ medium in a $37^{\circ} \mathrm{C}$ chamber and allowed to grow in chamber for one hour. $7 \mathrm{H} 9$ medium supplemented with N-QTF $(1 \mu \mathrm{M})$ was flowed into the chamber for six hours before switching media to N-QTF with and without antibiotic $(10 \mu \mathrm{g} / \mathrm{mL})$. Images were acquired every 15 min on an inverted Nikon TI-E microscope using a $60 \times$ objective. Cells were imaged using phase contrast and ex/em at 488/525 $\mathrm{nm}$.

\section{Cryo-transmission electron microscopy}

Cells were cultured to mid-log in complete $7 \mathrm{H} 9$ with and without frontline antibiotic treatment at 10 $\mu \mathrm{g} / \mathrm{mL}$ for four hours at $37^{\circ} \mathrm{C}$. After four hours, cells were concentrated 50 -fold by pelleting by centrifugation and resuspending in a 50-fold smaller volume. Concentrated cells were plunge-frozen in liquid ethane using an automated Leica EM GP system (Leica Microsystems) using R2/2 200 mesh grids (Quantifoil) and imaged using a Talos $120 \mathrm{kV}$ cryo-transmission electron microscope.

\section{Monocyte-derived macrophage differentiation and purification}

Adult human peripheral blood was acquired from Research Blood Components, LLC (Boston, MA, USA) under IRB approved protocol. Monocytes were isolated from whole blood by negative selection using RosetteSep human monocyte enrichment cocktail following the manufacturer's protocol (StemCell Technologies). Using density gradient medium (Lymphoprep) monocytes were isolated and differentiated into macrophages in the presence of GM-CSF (100 ng/mL) (R\&D Systems) in 1640 RPMI + 5\% FBS $+\mathrm{P} / \mathrm{S}$ media for 6 to 7 days

\section{Outermembrane vescicle isolation}

M.tb. H37Rv (500 mL) cultures were treated with DMSO, EMB or RIF at $15 \mathrm{ug} / \mathrm{mL}$ final concentration for six hours at $37^{\circ} \mathrm{C}$. Supernatant was centrifuged at 38,oooxg in a JA16.25 (Beckman Coulter) for 3 hours at $4^{\circ} \mathrm{C}$. After centrifugation, the supernatant was removed and the pellet was resuspended in 10 $\mathrm{mM}$ HEPES $150 \mathrm{mM} \mathrm{NaCl} \mathrm{pH} \mathrm{7.2.} \mathrm{OMV} \mathrm{concentration} \mathrm{as} \mathrm{normalized} \mathrm{using} \mathrm{absorbance} \mathrm{at} 280 \mathrm{~nm}$ and aliquoted into $100 \mu \mathrm{L}$ samples and stored at $-20^{\circ} \mathrm{C}$.

\section{OMV stimulation assay and Quantitative Real-Time PCR.}

Vehicle, EMB or RIF OMVs were added to wells containing $500 \mu \mathrm{L}$ of 750,000 cells $/ \mathrm{mL}$ and incubated at $37^{\circ} \mathrm{C}$ for 6 hours. After 6 hours, supernatant was removed, and washed with 2x Cold $1 \times$ PBS (1 mL). Trizol reagent $(400 \mu \mathrm{L})$ was added to the stimulation well. The supernatant was removed at $300 \mu \mathrm{L}$ of trizol was added. Total RNA was extracted with Trizol using Direct-zol RNA kits (Zymo Research). cDNA was generated by using an iScript cDNA synthesis kit (BioRad), and PCR amplification was performed in the presence of SYBR green (BioRad) in a CFX96 real-time PCR detection system (BioRad). Specific primers were designed using the PrimerQuest tool (Integrated DNA Technologies, Inc., Supplementary Table 1). Expression of specific genes was normalized to GAPDH expression ( $\Delta \mathrm{Ct}$ ), and expression fold change was calculated using the delta Ct method (2-( $\Delta \mathrm{Ct}$ Stim- $\Delta \mathrm{Ct}$ Unstim)) and normalized to LPS (50 $\mu \mathrm{g})$.

\section{Polar metabolite isolation}

OMV samples from DMSO, EMB, and RIF-treated conditions were extracted to analyze the metabolite composition within them. In an microcentrifuge tube, OMVs $(100 \mu \mathrm{L}, \mathrm{n}=3)$ were resuspended in $300 \mu \mathrm{L}$ of LC/MS grade methanol containing a mixture of 17 isotope-labeled amino acids (200 nM, Cambridge 
Isotope Laboratories, MSK-A2-1.2). To this solution, LC/MS grade water (150 $\mu \mathrm{L})$ was added to each tube. Ice cold amylenes-free chloroform $(200 \mu \mathrm{L})$ was added to each sample. The sample was vortexed at $4 \mathrm{C}$ for 1 minute and centrifuged for 10 minutes at 13,000xg at 4C. The top aqueous layer was removed and allowed to dry under N2 stream overnight. Dried Extracts were stored at -80C until run.

\section{Targeted metabolomics}

LC/MS was used to profile and quantify the polar metabolite contents of OMVs from DMSO, EMB, or RIF-treated M.tb.LC/MS-based analyses were performed as described previously(29) on a QExactive benchtop orbitrap mass spectrometer equipped with an Ion Max source and a HESI II probe coupled to a Dionex UltiMate 3000 UPLC system (Thermo Fisher Scientific). Metabolite sample (5 $\mu \mathrm{L})$ was injected onto a ZIC-pHILIC $2.1 \times 150 \mathrm{~mm}(5 \mu \mathrm{m}$ particle size) column (EMD Millipore). Buffer A was $20 \mathrm{mM}$ ammonium carbonate, $0.1 \%$ ammonium hydroxide; buffer $\mathrm{B}$ was acetonitrile. A flow rate of $0.150 \mathrm{ml} / \mathrm{min}$ was used for the chromatographic gradient. 0-20 min: linear gradient from $80 \%$ to $20 \% \mathrm{~B}$; 20-20.5 min: linear gradient from $20 \%$ to $80 \% \mathrm{~B} ; 20.5-28 \mathrm{~min}$ : hold at $80 \% \mathrm{~B}$. The mass spectrometer was operated in full-scan, polarity switching mode with the spray voltage set to $3.0 \mathrm{kV}$, the heated capillary held at $275^{\circ} \mathrm{C}$, and the HESI probe held at $350^{\circ} \mathrm{C}$. The sheath gas flow was set to 40 units, the auxiliary gas flow was set to 15 units, and the sweep gas flow was set to 1 unit. The MS data acquisition was performed in a range of 70-1000 m/z, with the resolution set at 70,000, the AGC target at $10^{6}$, and the maximum injection time at $80 \mathrm{~ms}$. XCalibur QuanBrowser 2.2 (Thermo Fisher Scientific) was used for metabolite identification and quantification using a 10 ppm mass accuracy window and $0.5 \mathrm{~min}$ retention time window compared to authentic metabolite standards. Within-batch mass deviation was typically $<0.0005 \mathrm{Da}$, and retention time deviation was $<0.25 \mathrm{~min}$. In each sample, the raw peak area for each metabolite was divided by the raw peak area of the relevant isotope-labeled internal standard to calculate the relative abundance.

\section{Detailed synthetic procedures}

Synthesis of 6-O-(15-[BODIPY-FL]-pentadeconyl)-6'-NH-DABCYL- $\alpha, \alpha$-trehalose/N-QTF 1 (See Figure $\mathrm{S} 1$ for overall route)

Dowex-50WX8-200 ion exchange resin (32 mg) was added to a solution of compound 5 (7.1 $\mathrm{mg}, 0.0044$ $\mathrm{mmol})$ in methanol $(1.25 \mathrm{~mL})$ and stirred at $\mathrm{rt}$ for $1 \mathrm{hr}$. The resin was removed by filtration and washed with methanol. The filtrate was concentrated under reduced pressure. Purification of the resulting residue by column chromatography $\left(\mathrm{SiO}_{2}, 10 \rightarrow 15 \% \mathrm{MeOH} / \mathrm{CH}_{2} \mathrm{Cl}_{2}\right)$ afforded the title compound 1 (3.24 mg, $62 \%)$ as an orange solid: $\mathrm{R}_{f}=0.20\left(10 \% \mathrm{MeOH} / \mathrm{CH}_{2} \mathrm{Cl}_{2}\right) ;{ }^{1} \mathrm{H} \mathrm{NMR}\left(500 \mathrm{MHz}, \mathrm{CD}_{3} \mathrm{OD}\right) \delta 7.97-7.95(\mathrm{~m}$, 2H), $7.88-7.85(\mathrm{~m}, 4 \mathrm{H}), 7.74(\mathrm{~s}, 1 \mathrm{H}), 7.42(\mathrm{~s}, 1 \mathrm{H}), 6.98(\mathrm{~d}, \mathrm{~J}=4.0 \mathrm{~Hz}, 1 \mathrm{H}), 6.86-6.84(\mathrm{~m}, 2 \mathrm{H}), 6.30(\mathrm{~d}$, $\mathrm{J}=4.0 \mathrm{~Hz}, 1 \mathrm{H}), 6.22(\mathrm{~s}, 1 \mathrm{H}), 5.10(\mathrm{t}, \mathrm{J}=4.1 \mathrm{~Hz}, 2 \mathrm{H}), 4.61(\mathrm{dd}, \mathrm{J}=11.9,2.1 \mathrm{~Hz}, 1 \mathrm{H}), 4.44(\mathrm{dd}, \mathrm{J}=11.8$, $5.4 \mathrm{~Hz}, 1 \mathrm{H}), 4.41(\mathrm{~s}, 2 \mathrm{H}), 4.39(\mathrm{dd}, \mathrm{J}=11.9,2.2 \mathrm{~Hz}, 1 \mathrm{H}), 4.32(\mathrm{t}, \mathrm{J}=7.1 \mathrm{~Hz}, 2 \mathrm{H}), 4.22-4.19(\mathrm{~m}, 2 \mathrm{H})$, 4.03 (ddd, $\mathrm{J}=10.2,5.5,2.2 \mathrm{~Hz}, 1 \mathrm{H}), 3.82(\mathrm{ddd}, \mathrm{J}=15.1,9.7,8.9 \mathrm{~Hz}, 2 \mathrm{H}), 3.54-3.47$ (m, 3H), 3.33 (dd, $\mathrm{J}=10.1,8.9 \mathrm{~Hz}, 2 \mathrm{H}), 3.25(\mathrm{t}, \mathrm{J}=7.6 \mathrm{~Hz}, 2 \mathrm{H}), 3.12(\mathrm{~s}, 6 \mathrm{H}), 2.66(\mathrm{t}, \mathrm{J}=7.6 \mathrm{~Hz}, 2 \mathrm{H}), 2.52(\mathrm{~s}, 3 \mathrm{H}), 2.34(\mathrm{t}, \mathrm{J}$ $=7.4 \mathrm{~Hz}, 2 \mathrm{H}), 2.28(\mathrm{~s}, 3 \mathrm{H}), 1.84(\mathrm{p}, \mathrm{J}=7.1 \mathrm{~Hz}, 2 \mathrm{H}), 1.61(\mathrm{p}, \mathrm{J}=7.3 \mathrm{~Hz}, 2 \mathrm{H}), 1.31-1.23(\mathrm{~m}, 20 \mathrm{H}) \mathrm{ppm}$; ${ }^{13} \mathrm{C}$ NMR (126 MHz, CD3OD) $\delta 174.1,173.2,160.0,155.1,153.3,144.9,144.4,143.4,135.2,134.3$, 133.5, 128.1, 128.0, 125.0, 124.4, 122.7, 121.6, 120.0, 116.3, 111.2, 94.0, 93.9, 73.2, 72.9, 72.1, 71.9, 71.8, 70.8, 70.4, 70.2, 62.9, 49.9, 48.2, 48.0, 47.9, 47.2, 47.1, 40.8, 39.0, 34.3, 33.7, 29.9, 29.3, 29.2, 29.1, 28.9, 28.7, 28.7, 26.0, 24.7, 13.5, 9.8 ppm; HRMS (ESI-TOF+) calcd for $\mathrm{C}_{59} \mathrm{H}_{81} \mathrm{BF}_{2} \mathrm{~N}_{10} \mathrm{O}_{13}(\mathrm{M}+\mathrm{H}+$ ) 1186.6155 , found 1187.6128 .

Synthesis of 6'-NH-DABCYL-2,3,4,2',3',4'-hexakis-O-(trimethylsilyl)- $\alpha, \alpha$-trehalose 3 DABCYL-OH (62 mg, $0.23 \mathrm{mmol}), \mathrm{EDC} \cdot \mathrm{HCl}(51 \mathrm{mg}, 0.26 \mathrm{mmol}), \mathrm{DMAP}(2.7 \mathrm{mg}, 0.02 \mathrm{mmol})$, and $\mathrm{HOBt}(41 \mathrm{mg}, 0.26)$ were dissolved in dry $\mathrm{CH}_{2} \mathrm{Cl}_{2}(1 \mathrm{~mL})$ and stirred at $\mathrm{rt}$ for $15 \mathrm{~min}$, then cooled to $0^{\circ} \mathrm{C}$. A solution of compound $2(187 \mathrm{mg}, 0.22 \mathrm{mmol})$ in dry $\mathrm{CH}_{2} \mathrm{Cl}_{2}(6 \mathrm{~mL})$ was added dropwise via cannula, 
and the reaction mixture kept at $0^{\circ} \mathrm{C}$ with slow addition of DIPEA $(192 \mu \mathrm{L})$. Reaction was allowed to warm to $\mathrm{rt}$ for $20 \mathrm{~h}$ and then concentrated under reduced pressure and resuspended in $\mathrm{CH}_{2} \mathrm{Cl}_{2}(20 \mathrm{~mL})$ and a cooled solution of $0.2 \mathrm{M} \mathrm{Na}_{2} \mathrm{CO}_{3} / \mathrm{NaHCO}_{3}$ buffer $\mathrm{pH}=9(20 \mathrm{~mL})$. The crude reaction mixture was immediately transferred to a separatory funnel extracted with $\mathrm{CH}_{2} \mathrm{Cl}_{2}$, washed with brine, and dried over $\mathrm{Na}_{2} \mathrm{SO}_{4}$ to afford crude material. Purification of the resulting residue by column chromatography $\left(\mathrm{SiO}_{2}\right.$, $\left.0 \rightarrow 8 \% \mathrm{EtOAc} / \mathrm{CH}_{2} \mathrm{Cl}_{2}\right)$ afforded the title compound $3(150 \mathrm{mg}, 66 \%)$ as an orange solid: $\mathrm{R}_{f}=0.35(30 \%$ EtOAc/hexanes); ${ }^{1} \mathrm{H}$ NMR $\left(400 \mathrm{MHz}, \mathrm{CDCl}_{3}\right) \delta 7.75-7.73(\mathrm{~m}, 2 \mathrm{H}), 7.71-7.73(\mathrm{~m}, 4 \mathrm{H}), 6.61-6.60$ (m, 2H), $6.30(\mathrm{~d}, \mathrm{~J}=3.1 \mathrm{~Hz}, 2 \mathrm{H}), 4.81(\mathrm{~d}, \mathrm{~J}=2.4 \mathrm{~Hz}, 1 \mathrm{H}), 4.75(\mathrm{~d}, \mathrm{~J}=3.7 \mathrm{~Hz}, 1 \mathrm{H}), 3.82(\mathrm{dq}, \mathrm{J}=8.4,2.7 \mathrm{~Hz}$, $1 \mathrm{H}), 3.80(\mathrm{t}, \mathrm{J}=8.9 \mathrm{~Hz}, 1 \mathrm{H}), 3.78(\mathrm{t}, \mathrm{J}=8.9 \mathrm{~Hz}, 1 \mathrm{H}), 3.75(\mathrm{dt}, \mathrm{J}=9.5,3.4 \mathrm{~Hz}, 1 \mathrm{H}), 3.33-3.29(\mathrm{~m}, 3 \mathrm{H})$, $3.26-3.20(\mathrm{~m}, 3 \mathrm{H}), 2.95(\mathrm{~s}, 6 \mathrm{H}), 1.42(\mathrm{dd}, \mathrm{J}=7.4,5.3 \mathrm{~Hz}, 1 \mathrm{H}), 0.04(\mathrm{~s}, 9 \mathrm{H}), 0.00(\mathrm{~s}, 9 \mathrm{H}), 0.00(\mathrm{~s}, 9 \mathrm{H})$, $0.01(\mathrm{~s}, 9 \mathrm{H}),-0.01(\mathrm{~s}, 9 \mathrm{H}),-0.11(\mathrm{~s}, 9 \mathrm{H}) \mathrm{ppm} ;{ }^{13} \mathrm{C} \mathrm{NMR}(101 \mathrm{MHz}, \mathrm{CDCl} 3) \mathrm{d} 166.7,154.9,152.7,143.5$, 134.4, 127.7, 125.3, 122.1, 111.4, 94.2, 93.8, 73.9, 73.2, 73.1, 73.0, 72.9, 72.7, 72.6, 71.3, 61.6, 41.4, 40.2, 0.94, 0.91, 0.75, 0.23, 0.00, 0.00 ppm; HRMS (ESI-TOF+) calcd for $\mathrm{C}_{45} \mathrm{H}_{84} \mathrm{~N}_{4} \mathrm{O}_{11} \mathrm{Si}_{6}(\mathrm{M}+\mathrm{H}+$ ) 1025.4825 , found 1025.44830 .

Synthesis of 6-O-(15-azidopentadeconyl)-6'-NH-DABCYL-2,3,4,2 ',3',4'-hexakis-O-(trimethylsilyl)- $\alpha, \alpha-$ trehalose 4

15-Azidopentadecanoic acid (23 $\mathrm{mg}, 0.082 \mathrm{mmol}), \mathrm{EDC} \cdot \mathrm{HCl}(31 \mathrm{mg}, 0.164 \mathrm{mmol})$ and DMAP (6 mg, $0.049 \mathrm{mmol}$ ) were dissolved in dry $\mathrm{CH}_{2} \mathrm{Cl}_{2}(0.5 \mathrm{~mL})$ and stirred at $\mathrm{rt}$ for $15 \mathrm{~min}$. A solution of compound $3(42 \mathrm{mg}, 0.041 \mathrm{mmol})$ in dry $\mathrm{CH}_{2} \mathrm{Cl}_{2}(1 \mathrm{~mL})$ was added dropwise via cannula, and the reaction mixture stirred at $\mathrm{rt}$ for $16 \mathrm{~h}$ and then concentrated under reduced pressure. Purification of the resulting residue by column chromatography $\left(\mathrm{SiO}_{2}, 0 \rightarrow 4 \%\right.$ EtOAc/hexanes) afforded the title compound 4 (36 mg, 69\%) as an orange solid: $\mathrm{R}_{f}=0.33\left(10 \%\right.$ EtOAc/hexanes); ${ }^{1} \mathrm{H} \mathrm{NMR}\left(400 \mathrm{MHz}, \mathrm{CDCl}_{3}\right) \delta 7.74(\mathrm{~m}, 2 \mathrm{H}), 7.72-$ $7.67(\mathrm{~m}, 4 \mathrm{H}), 6.61-6.58(\mathrm{~m}, 2 \mathrm{H}), 5.13(\mathrm{t}, \mathrm{J}=3.6 \mathrm{~Hz}, 2 \mathrm{H}), 4.82(\mathrm{dd}, \mathrm{J}=12.0,2.4 \mathrm{~Hz}, 1 \mathrm{H}), 4.17(\mathrm{ddd}, \mathrm{J}=$ 11.2, 7.9, 2.8 Hz, 2H), $3.91-3.72(\mathrm{~m}, 5 \mathrm{H}), 3.31(\mathrm{t}, \mathrm{J}=9.0 \mathrm{~Hz}, 1 \mathrm{H}), 3.27-3.21(\mathrm{~m}, 3 \mathrm{H}), 3.08(\mathrm{t}, \mathrm{J}=7.0$ $\mathrm{Hz}, 2 \mathrm{H}), 2.94(\mathrm{~s}, 6 \mathrm{H}), 2.19(\mathrm{td}, \mathrm{J}=7.5,3.5 \mathrm{~Hz}, 2 \mathrm{H}), 1.48-1.39(\mathrm{~m}, 4 \mathrm{H}), 1.20-1.08(\mathrm{~m}, 20 \mathrm{H}), 0.04(\mathrm{~s}$, $9 \mathrm{H}), 0.00(\mathrm{~s}, 9 \mathrm{H}),-0.01(\mathrm{~s}, 9 \mathrm{H}),-0.01(\mathrm{~s}, 9 \mathrm{H}),-0.03(\mathrm{~s}, 9 \mathrm{H}),-0.12(\mathrm{~s}, 9 \mathrm{H}) \mathrm{ppm} ;{ }^{13} \mathrm{C} \mathrm{NMR}(101 \mathrm{MHz}$, CDCl3) $\delta 172.7,165.7,154.0,151.7,142.6,133.5,133.4,126.8,124.3,121.2,110.4,72.9,72.5,72.3$, $72.2,72.0,71.8,71.7,71.5,70.8,70.4,70.1,69.8,62.2,61.3,52.4,50.4,40.5,39.2,33.1,28.6,28.5,28.4$, 28.4, 28.3, 28.1, 28.1 27.8, 25.6, 23.7 0.00, 0.00, 0.00, -0.18, -0.88, -0.94 ppm; HRMS (ESI-TOF+) calcd for $\mathrm{C}_{60} \mathrm{H}_{111} \mathrm{~N}_{7} \mathrm{O}_{12} \mathrm{Si}_{6}(\mathrm{M}+\mathrm{H}+)$ 1290.6979, found 1290.6980

Synthesis of 6-O-(15-[BODIPY-FL]-pentadeconyl)-6'-NH-DABCYL-2,3,4,2',3',4'-hexakis-O(trimethylsilyl)- $\alpha, \alpha$-trehalose 5

Compound 4 (12 mg, $0.009 \mathrm{mmol})$ and BODIPY-FL alkyne (3 mg, 0.009 mmol) were dissolved in 5:5:1 t-BuOH: $\mathrm{H}_{2} \mathrm{O}: \mathrm{CH}_{2} \mathrm{Cl}_{2}$ (1.5 mL total). To this solution were added TBTA (97 $\mu \mathrm{g}$ in $96.7 \mu \mathrm{L} \mathrm{CH}_{2} \mathrm{Cl}_{2}$, $0.0018 \mathrm{mmol})$, sodium ascorbate $(18 \mu \mathrm{L}$ of a $0.1 \mathrm{M}$ aqueous solution, $0.0018 \mathrm{mmol})$, and $\mathrm{CuSO}_{4} \cdot 5 \mathrm{H}_{2} \mathrm{O}(9$ $\mu \mathrm{L}$ of a $0.1 \mathrm{M}$ aqueous solution, $0.0009 \mathrm{mmol})$. The resulting mixture was stirred vigorously in the dark for $48 \mathrm{~h}$, and then concentrated under reduced pressure. Purification of the resulting residue by column chromatography ( $\mathrm{SiO} 2,40 \rightarrow 90 \%$ EtOAc/hexanes) afforded the title compound $\mathbf{5}(11.2 \mathrm{mg}, 76 \%)$ as an orange solid: $\mathrm{R}_{f}=0.15(50 \%$ EtOAc/hexanes $) ;{ }^{1} \mathrm{H}$ NMR $\left(500 \mathrm{MHz}, \mathrm{CDCl}_{3}\right) \delta 7.74-7.67(\mathrm{~m}, 2 \mathrm{H}), 7.70-$ $7.67(\mathrm{~m}, 4 \mathrm{H}), 7.10(\mathrm{~s}, 1 \mathrm{H}), 6.90(\mathrm{~s}, 1 \mathrm{H}), 6.68(\mathrm{~d}, \mathrm{~J}=4.0 \mathrm{~Hz}, 1 \mathrm{H}), 6.60(\mathrm{~d}, \mathrm{~J}=4 \mathrm{~Hz}, 1 \mathrm{H}), 6.31-6.29(\mathrm{~m}$, 2H), $6.07(\mathrm{~m}, 1 \mathrm{H}), 5.95(\mathrm{~s}, 1 \mathrm{H}), 4.82(\mathrm{dd}, \mathrm{J}=5.2,3.1 \mathrm{~Hz}, 2 \mathrm{H}), 4.75(\mathrm{dd}, \mathrm{J}=11.9,2.4 \mathrm{~Hz}, 1 \mathrm{H}), 4.32(\mathrm{~d}, \mathrm{~J}=$ $5.8 \mathrm{~Hz}, 2 \mathrm{H}), 4.17-4.09(\mathrm{~m}, 4 \mathrm{H}), 3.96(\mathrm{dt}, \mathrm{J}=9.5,3.0 \mathrm{~Hz}, 1 \mathrm{H}), 3.90(\mathrm{dd}, \mathrm{J}=11.8,4.5 \mathrm{~Hz}, 1 \mathrm{H}), 3.88$ (ddd, $\mathrm{J}=9.6,4.5,2.3 \mathrm{~Hz}, 1 \mathrm{H}), 3.81(\mathrm{t}, \mathrm{J}=8.9 \mathrm{~Hz}, 1 \mathrm{H}), 3.80(\mathrm{t}, \mathrm{J}=8.9 \mathrm{~Hz}, 1 \mathrm{H}), 3.75(\mathrm{t}, \mathrm{J}=9.1 \mathrm{~S} 4 \mathrm{~Hz}, 1 \mathrm{H})$, $3.33-3.23(\mathrm{~m}, 3 \mathrm{H}), 3.22(\mathrm{t}, \mathrm{J}=7.5 \mathrm{~Hz}, 2 \mathrm{H}), 2.94(\mathrm{~s}, 6 \mathrm{H}), 2.48(\mathrm{t}, \mathrm{J}=7.6 \mathrm{~Hz}, 2 \mathrm{H}), 2.39(\mathrm{~s}, 3 \mathrm{H}), 2.23-$ 2.15 (m, 2H), 2.08 (s, 3H), 1.69 (q, J = 7.3 Hz, 2H), $1.46-1.43$ (m, 4H), $1.13-1.07$ (m, 18H), 0.04 (s, 
9H), $0.00(\mathrm{~s}, 9 \mathrm{H}),-0.01(\mathrm{~s}, 9 \mathrm{H}),-0.01(\mathrm{~s}, 9 \mathrm{H}), 0.03(\mathrm{~s}, 9 \mathrm{H}),-0.12(\mathrm{~s}, 9 \mathrm{H}) \mathrm{ppm} ;{ }^{13} \mathrm{C} \mathrm{NMR}(126 \mathrm{MHz}$, $\left.\mathrm{CDCl}_{3}\right) \delta 172.7,170.2,165.7,159.4,156.0,154.0,151.8,142.9 .9,142.6,134.2,133.4,132.3,127.0$, $126.8,124.4,122.7,121.2,121.0,119.5,116.2,110.4,93.1,92.7,72.9,72.0,71.8,71.5,70.8,70.3,69.8$, $62.2,49.3,40.5,39.3,34.8,34.0,33.1,29.2,28.7,28.6,28.5,28.4,28.4,28.3,28.1,28.0,25.5,23.8,13.9$, $13.2,13.1,10.3,0.2,0.0,-0.2,-0.2,-0.9,-0.9$; HRMS (ESI-TOF+) calcd for $\mathrm{C}_{77} \mathrm{H}_{129} \mathrm{BF}_{2} \mathrm{~N}_{10} \mathrm{O}_{13} \mathrm{Si}_{6}$ $[(\mathrm{M}+2 \mathrm{H}+) / 2] 810.4281$, found 810.4282

Fig. S1.

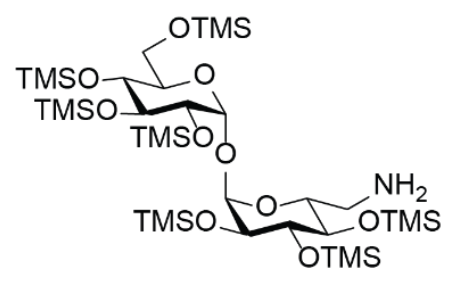

2
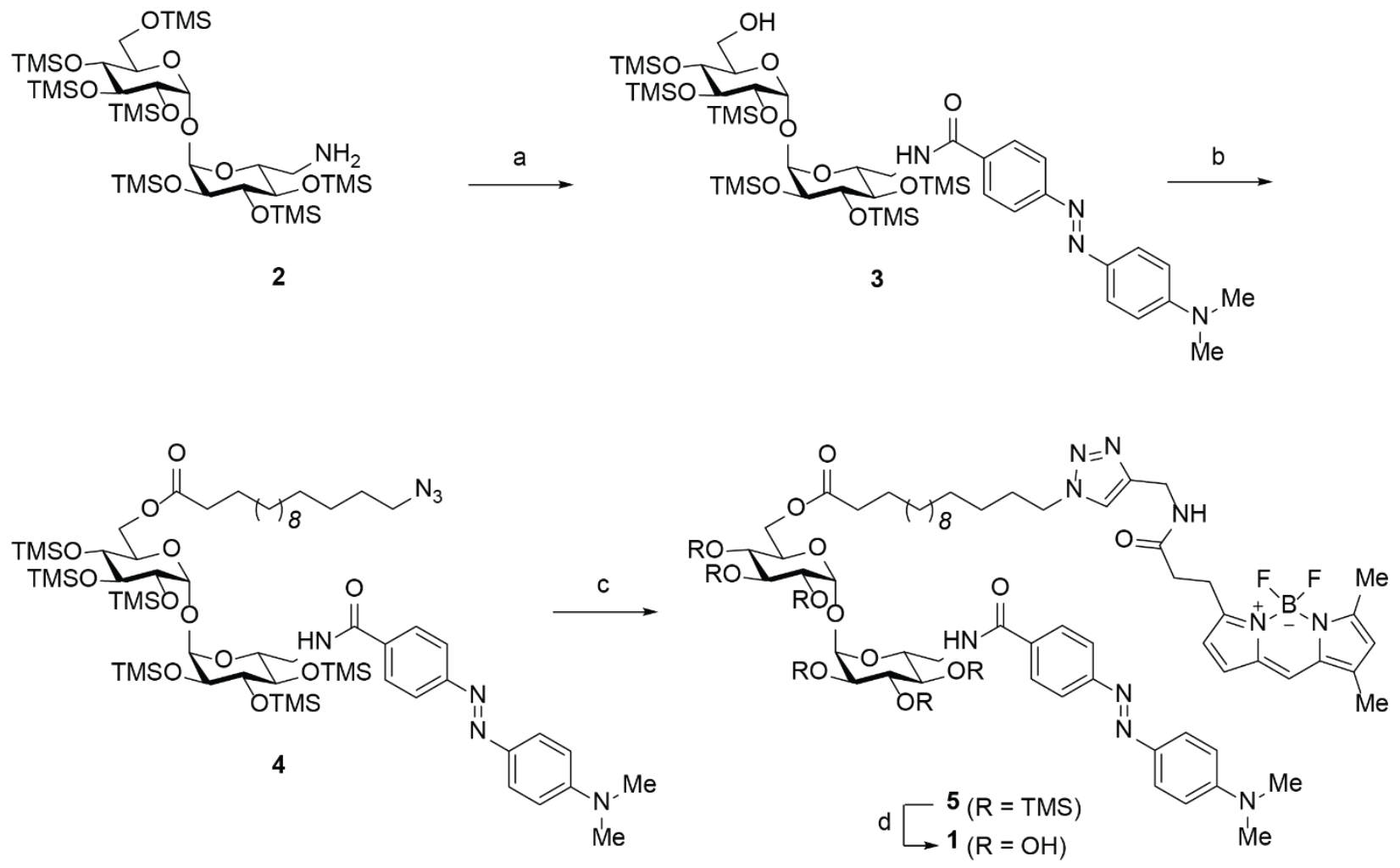

Synthetic scheme for the preparation of N-QTF. Reagents and conditions: a) DABCYL-OH, EDC•HCl, DMAP, HOBt, $\mathrm{CH}_{2} \mathrm{Cl}_{2}$, rt, $16 \mathrm{~h}, 66 \%$ b) 15-azidopentadecanoic acid, EDC•HCl, DMAP, $\mathrm{CH}_{2} \mathrm{Cl}_{2}$, rt, 16 h, 69\%; c) BODIPY-FL-alkyne, $\mathrm{CuSO}_{4} \bullet 5 \mathrm{H}_{2} \mathrm{O}$, sodium ascorbate, TBTA, t-BuOH: $\mathrm{H}_{2} \mathrm{O}: \mathrm{CH}_{2} \mathrm{Cl}_{2}(5: 5: 1)$, rt, 24 h, 76\%; d) Dowex-H+, MeOH, rt, 15 min 62\%. 


\section{Fig. S2.}

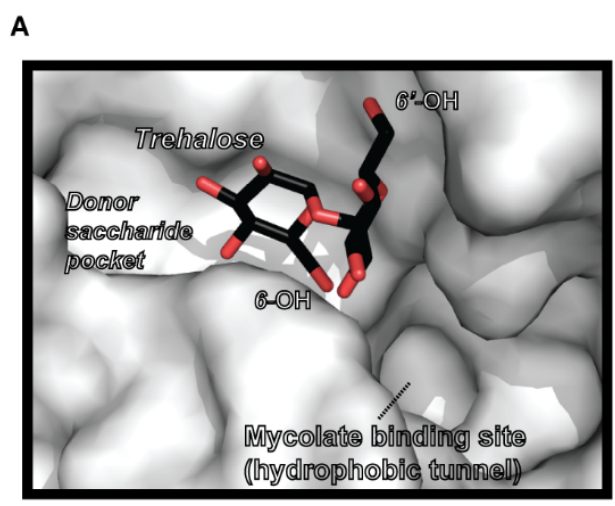

B

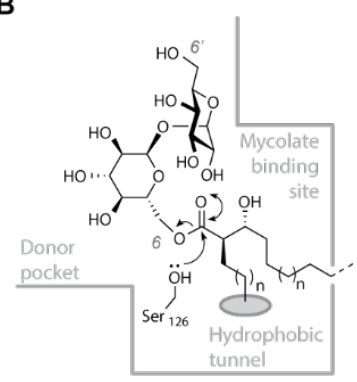

TMM
C

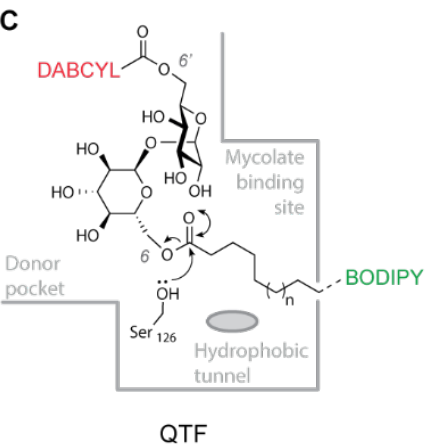

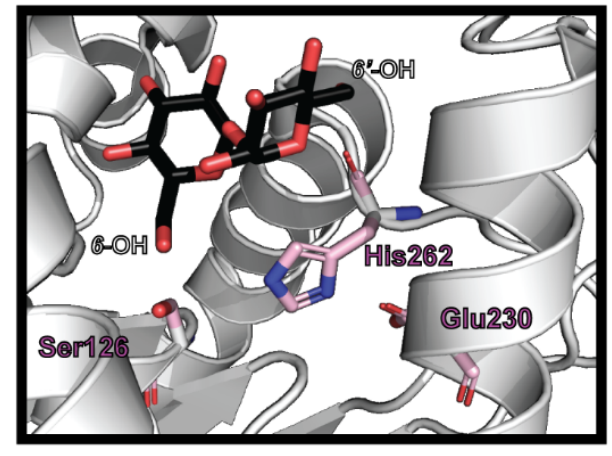

D

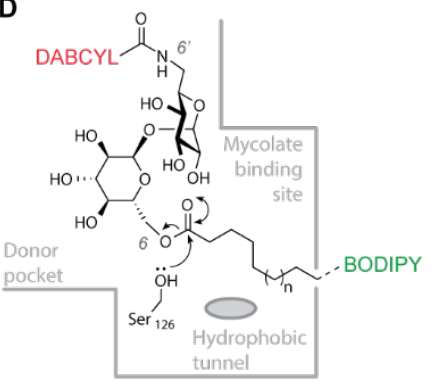

N-QTF

Substrate design. Substrate mimics were designed by leveraging the binding mode of the native substrate of antigen 85(30). (A) Left: Trehalose is shown proximal to the mycolate binding site to yield the trehalose monomycolate (TMM) substrate. Right: The catalytic triad residues (pink) Ser126, His262, and Glu230 are positioned next to the trehalose substrate for fatty acyl transfer. PDB: 1FoP (B) Mechanism of acyl transfer by the nucleophilic serine residue. (C) QTF substrate mimic predicts an analogous mechanism. (D) N-QTF increases the thermodynamic stability of the C6'-DABCYL-linked motif. 
Fig. S3.

A
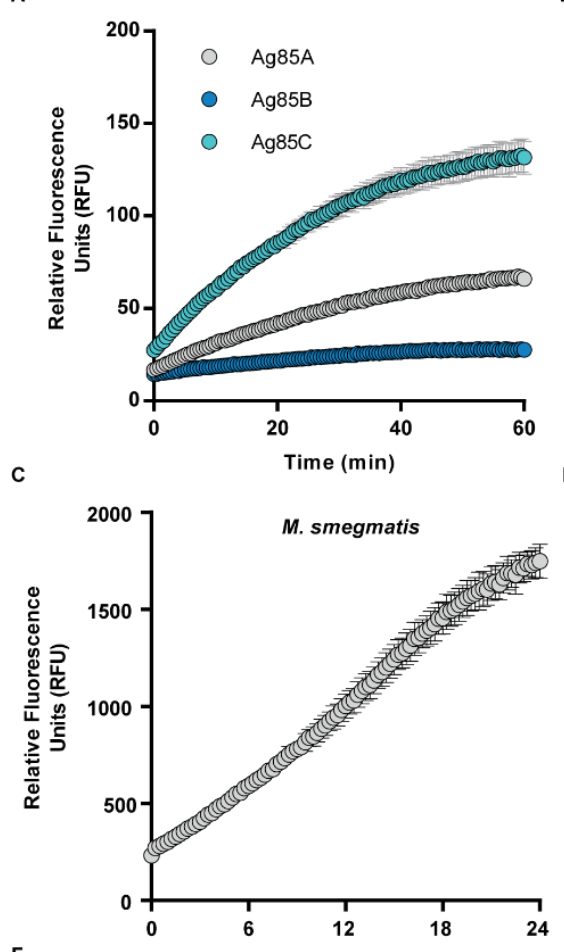

$\mathbf{F}$

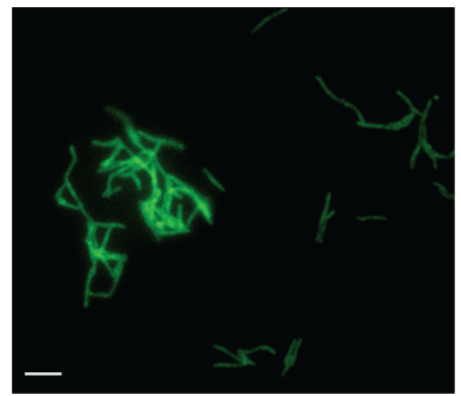

B
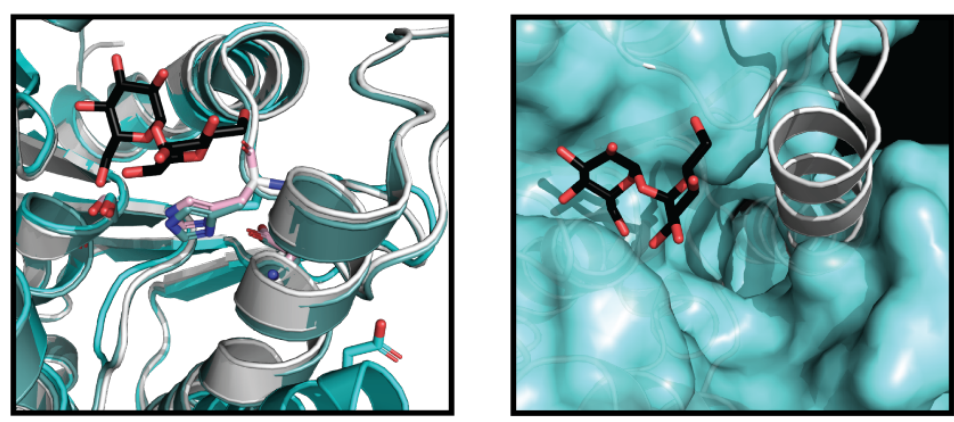

D
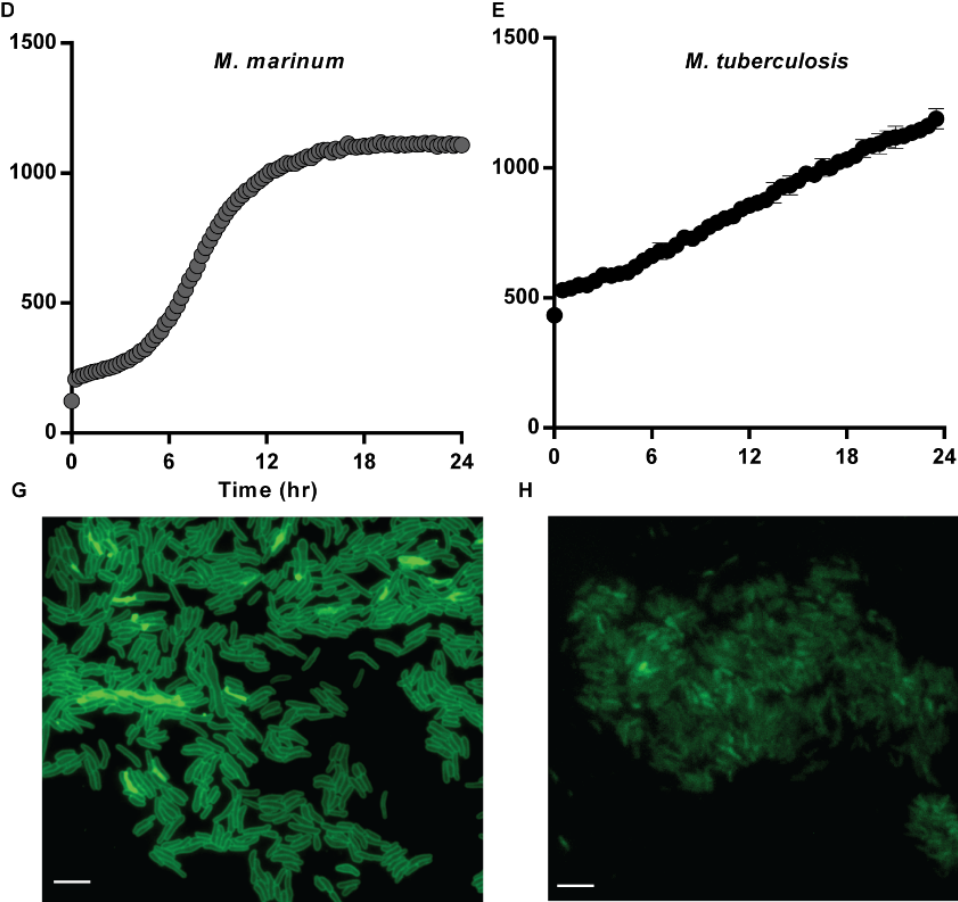

H

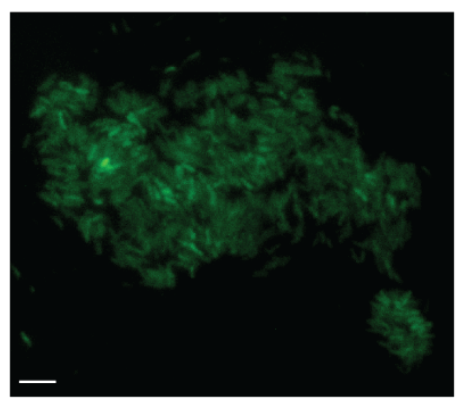

N-QTF activation by Antigen 85 complex and Mycobacterial species. N-QTF $(5 \mu \mathrm{M})$ activation by (A) antigen 85A (fbpA, Rv3804c, gray), antigen 85B (fbpB, Rv1886c, marine), and antigen 85C (fbpD, Rv3803, cyan). (B) Left: Structural alignment of Ag85A-C show conservation of catalytic cysteine and histidine residues. Right: overlay of Ag85A (PDB: 1FoP, gray) and Ag85C (PDB: 4MQM, cyan) shows an expanded hydrophobic tunnel(31). Incorporation of N-QTF over time and endpoint visualization in mycobacterial species (C, F) M. smegmatis (D, G) M. marinum and (E, H) Mtb. Scale bar $5 \mu \mathrm{m}$. 


\section{Fig. S4.}

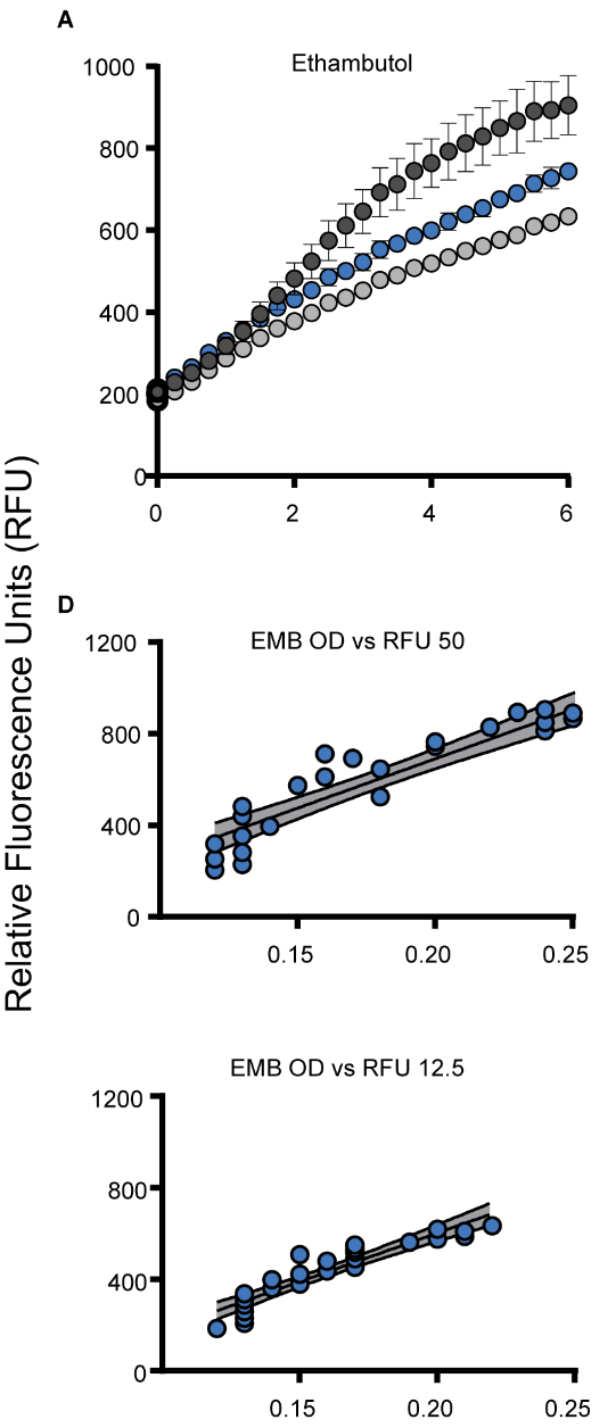

B



E

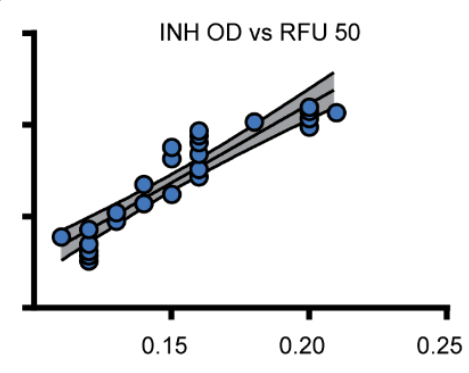

INH OD vs RFU 12.5



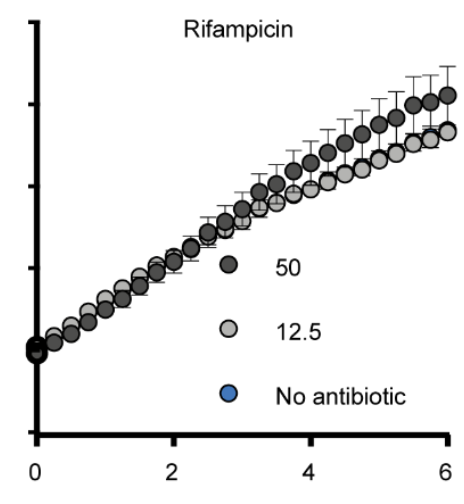

$\mathbf{F}$

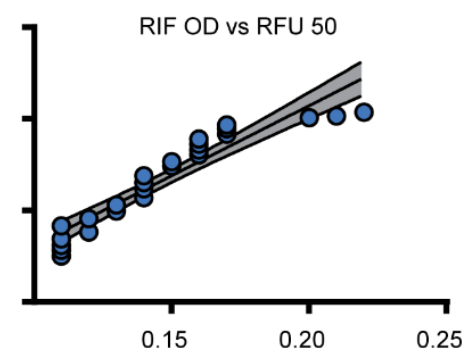

RIF OD vs RFU 12.5

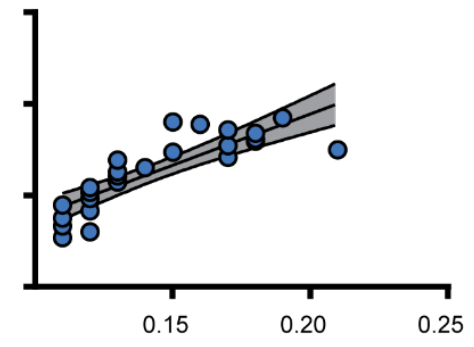

Fluorescence activation over time with frontline antibiotic treatment. Time-dependent changes in N-QTF treatment in the presence of frontline antibiotics (A) ethambutol (EMB), (B), isoniazid (INH), and (C) rifampicin (RIF) at $50 \mu \mathrm{g} / \mathrm{mL}$ (slate), $12.5 \mu \mathrm{g} / \mathrm{mL}$ (grey), and vehicle control (blue). Linear correlation plots of optical density $\left(\mathrm{OD}_{600}\right)$ vs relative fluorescence units (RFU) upon (D) EMB, (E) INH, and (F) RIF treatment at $50 \mu \mathrm{g} / \mathrm{mL}$ (top) and $12.5 \mu \mathrm{g} / \mathrm{mL}$ (bottom) antibiotic concentration. 


\section{Fig. S5.}

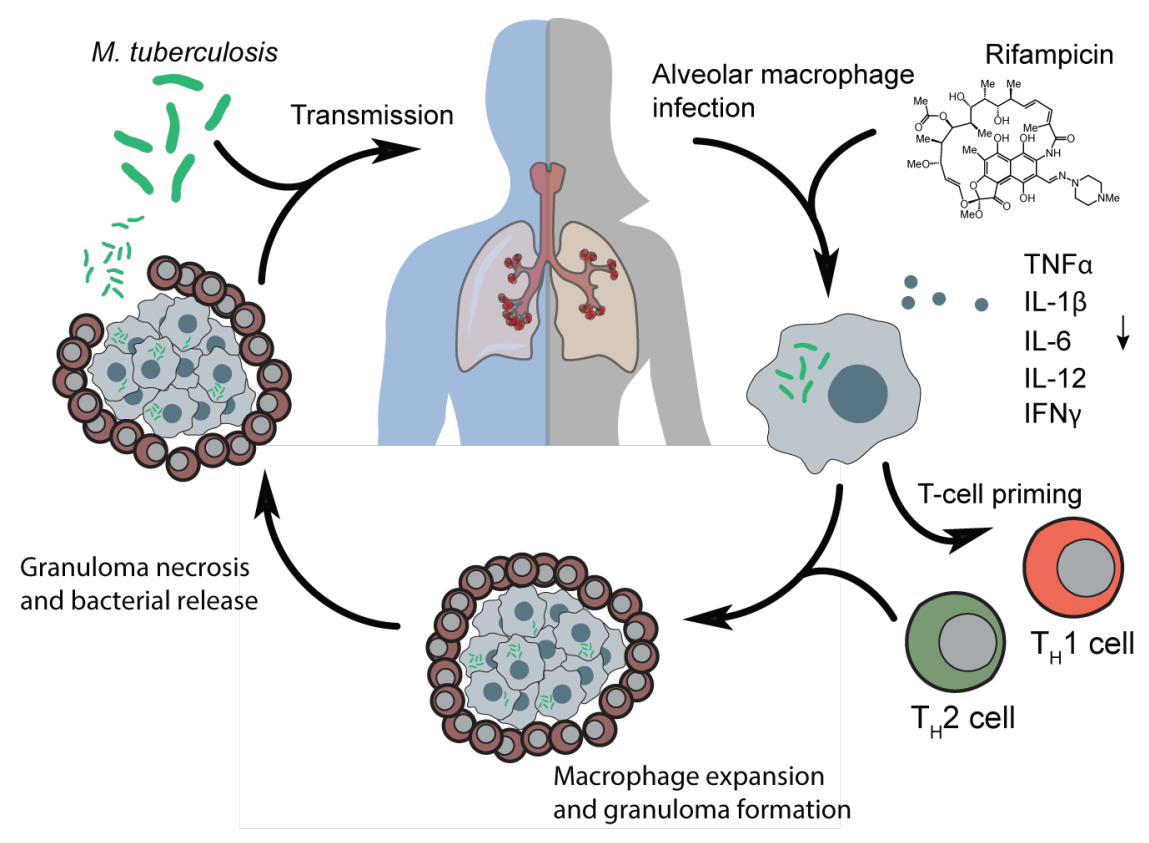

Mechanism of immune modulation following rifampicin treatment. $M$. tuberculosis infection cycle. Transmission and infection into human alveolar macrophages induces a proinflammatory immune response in normal clearance. Rifampicin-treatment induces the secretion of outer membrane vesicles that modulates macrophages which affects immune cell recruitment. 
bioRxiv preprint doi: https://doi.org/10.1101/2022.01.07.475452; this version posted January 9, 2022. The copyright holder for this preprint (which was not certified by peer review) is the author/funder, who has granted bioRxiv a license to display the preprint in perpetuity. It is made available under aCC-BY-NC-ND 4.0 International license.

Table S1. Real time qPCR primer sequences

\begin{tabular}{|c|c|c|c|}
\hline Gene & $\begin{array}{l}\text { Gene } \\
\text { ID }\end{array}$ & Forward Primer & Reverse Primer \\
\hline Il-1b & 3553 & CACCTGTACGATCACTGAACTG & ACCACTTGTTGCTCCATATCC \\
\hline IL-6 & 3569 & TGCAATAACCACCCCTGACC & TGCGCAGAATGAGATGAGTTG \\
\hline IL-12a & 3592 & $\begin{array}{l}\text { TGAGCTATCTGAATGCTTCCTA } \\
\text { AA }\end{array}$ & $\begin{array}{l}\text { CCCTAGTTCTTAATCCACATCCT } \\
\text { ATC }\end{array}$ \\
\hline IL-12b & 3593 & CACAGGAGGATGACACAGAAA & $\begin{array}{l}\text { ACAATTTCATGTCCTTAGCCATA } \\
\text { AC }\end{array}$ \\
\hline TNFa & 7124 & AGAGGGAGAGAAGCAACTACA & GGGTCAGTATGTGAGAGGAAGA \\
\hline IFNa & 3439 & $\begin{array}{l}\text { AGGAATAACATCTGGTCCAACA } \\
\mathrm{T}\end{array}$ & $\begin{array}{l}\text { TCAGTTTATCAGCATGGTCATAG } \\
\text { TT }\end{array}$ \\
\hline IFNb & 3456 & GCCGCATTGACCATCTATGA & GCCAGGAGGTTCTCAACAATAG \\
\hline IFNg & 3458 & GGGTTCTCTTGGCTGTTACT & GAGTTCCATTATCCGCTACATCT \\
\hline GAPDH & 2597 & CCATGTTCGTCATGGGTGTG & GGTGCTAAGCAGTTGGTGGTG \\
\hline
\end{tabular}


bioRxiv preprint doi: https://doi.org/10.1101/2022.01.07.475452; this version posted January 9, 2022. The copyright holder for this preprint (which was not certified by peer review) is the author/funder, who has granted bioRxiv a license to display the preprint in perpetuity. It is made available under aCC-BY-NC-ND 4.0 International license.

\section{Table S2. Area ratios of targeted polar metabalomics of OMVs}

\begin{tabular}{|c|c|c|c|c|c|c|c|c|c|c|c|c|}
\hline & DMSO OMVE1 & DMSO OMV E2 & DMSO OMV E3 & OMVE1 & OMVE2 & OMVE3 & DMSO OMV R1 & DMSO OMVR2 & DMSO OMV R3 & OMV R1 & OMV R2 & OMV R3 \\
\hline ethylnicotinamide & 0 & 0 & 0 & 0 & 0 & 0 & 0 & 0 & 0 & 0 & 0 & \\
\hline 2,3-BPG & 0 & 0 & 0 & 0 & 0 & 0 & 0.013 & 0.017 & 0.022 & 0.022 & 0.021 & 0.019 \\
\hline 2-aminoadipate & 1.806 & 1.935 & 1.731 & 2.261 & 2.343 & 2.269 & 0.316 & 0.305 & 0 & 0 & 0.151 & 0.328 \\
\hline -hydroxyglutarate & 1.867 & 2.104 & 1.742 & 1.928 & 2.053 & 2.118 & 5.235 & 4.113 & 4.379 & 5.791 & 5.264 & 5.628 \\
\hline 2-oxoadipate & 0 & 0 & 0 & 0 & 0 & 0 & 0 & 0 & 0 & 0 & 0 & 0 \\
\hline 3-hydroxybutyrate & 0 & 0.007 & 0 & 0.015 & 0.005 & 0.009 & 0 & 0 & 0 & 0.005 & 0 & 0 \\
\hline phosphoglycerate & 0.007 & 0.005 & 0.006 & 0.004 & 0.008 & 0.006 & 0.01 & 0.011 & 0.012 & 0.023 & 0.021 & 0.025 \\
\hline ureidopropionate & 0 & 0 & 0 & 0 & 0 & 0 & 0 & 0 & 0 & 0 & 0 & 0 \\
\hline yindole_3-acetate & 0 & 0 & 0 & 0 & 0 & 0 & 0 & 0 & 0 & 0 & 0 & 0 \\
\hline phosphogluconate & 0 & 0 & 0 & 0 & 0 & 0 & 0 & 0 & 0 & 0 & 0 & 0 \\
\hline acetoacetate & 0 & 0 & 0 & 0 & 0 & 0 & 0 & 0 & 0 & 0 & 0 & 0 \\
\hline acetylcarnitine & 0 & 0.01 & 0.008 & 0.006 & 0.004 & 0.014 & 0.007 & 0.005 & 0.003 & 0.001 & 0.005 & 0.009 \\
\hline acetyl-CoA & 0 & 0 & 0 & 0 & 0 & 0 & 0 & 0 & 0 & 0 & 0 & 0 \\
\hline acetylserine & 0.471 & 0.657 & 0.774 & 0.744 & 0.547 & 0.683 & 0.493 & 0.115 & 0.023 & 0.134 & 0.184 & 0.091 \\
\hline adenine & 2.517 & 2.064 & 1.809 & 2.61 & 2.066 & 1.974 & 0.078 & 0.074 & 0.071 & 0.385 & 0.333 & 0.338 \\
\hline adenosine & 0.086 & 0.08 & 0.07 & 0.116 & 0.092 & 0.087 & 0.05 & 0.045 & 0.051 & 0.303 & 0.386 & 0.311 \\
\hline & 0 & 0 & 0 & 0 & 0 & 0 & 0 & 0 & 0 & 0 & 0 & 0 \\
\hline ADP-ribose & 0 & 0 & 0 & 0 & 0 & 0 & 0 & 0 & 0 & 0 & 0 & \\
\hline AICAR & 0 & 0 & 0 & 0 & 0 & 0 & 0 & 0 & 0 & 0 & 0 & 0 \\
\hline alanine & 2.906 & 2.776 & 3.195 & 3.564 & 3.592 & 3.305 & 0.509 & 0.188 & 0.11 & 0.249 & 0.222 & 0.24 \\
\hline alanine_13C3-15N & 0 & 0 & 0 & 0 & 0 & 0 & 0 & 0 & 0 & 0 & 0 & 0 \\
\hline allantoin & 0 & 0 & 0 & 0 & 0 & 0 & 0 & 0 & 0 & 0 & 0 & 0 \\
\hline pha-ketoglutarate & 0.22 & 0.292 & 0.297 & 0.208 & 0.219 & 0.262 & 0.522 & 0.482 & 0.444 & 3.093 & 1.429 & 1.463 \\
\hline alpha-lipoic_acid & 0 & 0 & 0 & 0 & 0 & 0 & 0 & 0 & 0 & 0 & 0 & 0 \\
\hline AMP & 0.161 & 0.151 & 0.182 & 0.156 & 0.177 & 0.176 & 0.303 & 0.26 & 0.269 & 0.438 & 0.342 & 0.389 \\
\hline anserine & 0 & 0 & 0 & 0 & 0 & 0 & 0 & 0 & 0 & 0 & 0 & 0 \\
\hline arginine & 0.086 & 0.091 & 0.108 & 0.116 & 0.111 & 0.102 & 0.162 & 0.038 & 0.016 & 0.067 & 0.084 & 0.062 \\
\hline ginine_13C6-15N4 & 0 & 0 & 0 & 0 & 0 & 0 & 0 & 0 & 0 & 0 & 0 & 0 \\
\hline argininosuccinate & 0 & 0 & 0 & 0 & 0 & 0 & 0 & 0 & 0 & 0 & 0 & \\
\hline asparagine & 0.001 & 0.001 & 0.002 & 0.003 & 0.002 & 0.001 & 0.003 & 0.001 & 0 & 0.002 & 0.002 & 0.002 \\
\hline aspartate & 0.173 & 0.211 & 0.317 & 0.239 & 0.215 & 0.208 & 2.934 & 2.966 & 2.96 & 3.08 & 2.955 & 3.033 \\
\hline partate_13C4-15N & 0 & 0 & 0 & 0 & 0 & 0 & 0 & 0 & 0 & 0 & 0 & 0 \\
\hline ATP & 0 & 0 & 0 & 0 & 0 & 0 & 0 & 0 & 0 & 0 & 0 & \\
\hline beta-alanine & 1.396 & 1.332 & 1.627 & 1.711 & 1.714 & 1.256 & 0.266 & 0.165 & 0.203 & 0.318 & 0.276 & 0.285 \\
\hline betaine & 0.088 & 0.159 & 0.143 & 0.183 & 0.133 & 0.156 & 0.308 & 0.134 & 0.167 & 0.175 & 0.148 & 0.154 \\
\hline butyryl_carnitine & 0 & 0 & 0 & 0 & 0 & 0 & 0 & 0 & 0 & 0 & 0 & 0 \\
\hline C5_carnitines & 0 & 0 & 0 & 0 & 0 & 0 & 0 & 0 & 0 & 0 & 0 & \\
\hline CAMP & 0.03 & 0.024 & 0.022 & 0.01 & 0.008 & 0.009 & 0 & 0 & 0.002 & 0.02 & 0.017 & 0.017 \\
\hline bamoyl_aspartate & 0 & 0 & 0 & 0 & 0 & 0 & 0.043 & 0.042 & 0.049 & 0.046 & 0.045 & 0.044 \\
\hline carnitine & 0.024 & 0.036 & 0.042 & 0.049 & 0.051 & 0.076 & 0.05 & 0.024 & 0.014 & 0.015 & 0.032 & 0.037 \\
\hline carnosine & 0 & 0 & 0 & 0 & 0 & 0 & 0 & 0 & 0 & 0 & 0 & 0 \\
\hline CDP & 0 & 0 & 0 & 0 & 0 & 0 & 0 & 0 & 0 & 0 & 0 & 0 \\
\hline choline & 0.68 & 0.857 & 0.696 & 0.891 & 0.769 & 0.896 & 0.831 & 0.38 & 0.34 & 0.573 & 0.58 & 0.525 \\
\hline cis-aconitate & 0 & 0.007 & 0.006 & 0.006 & 0.006 & 0.008 & 0 & 0 & 0 & 0 & 0 & \\
\hline citrate & 115.567 & 127.041 & 124.947 & 125.454 & 128.045 & 118.281 & 66.324 & 61.571 & 68.467 & 87.937 & 88.961 & 93.224 \\
\hline citrulline & 0.298 & 0.329 & 0.74 & 0.392 & 0.436 & 0.394 & 0.463 & 0.149 & 0.058 & 0.059 & 0.056 & 0.064 \\
\hline CMP & 0.006 & 0.014 & 0.006 & 0.006 & 0 & 0.003 & 0.035 & 0.043 & 0.04 & 0.041 & 0.035 & 0.023 \\
\hline creatine & 0.003 & 0.004 & 0.005 & 0.007 & 0.004 & 0.01 & 0.013 & 0.003 & 0 & 0 & 0.005 & 0.004 \\
\hline creatinine & 0.01 & 0.01 & 0.007 & 0.015 & 0.01 & 0.007 & 0.03 & 0.01 & 0.004 & 0.005 & 0.008 & 0.009 \\
\hline CTP & 0 & 0 & 0 & 0 & 0 & 0 & 0 & 0 & 0 & 0 & 0 & 0 \\
\hline cystathionine & 0 & 0 & 0 & 0 & 0 & 0 & 0 & 0 & 0 & 0 & 0 & \\
\hline cysteine & 0 & 0 & 0 & 0 & 0 & 0 & 0 & 0 & 0 & 0 & 0 & 0 \\
\hline cystine & 1.009 & 0 & 0 & 1.131 & 0.709 & 0.702 & 0 & 0.216 & 0 & 0 & 0.236 & 0.248 \\
\hline cytidine & 0 & 0.001 & 0 & 0 & 0.001 & 0 & 0.003 & 0.001 & 0.001 & 0.002 & 0.001 & 0.004 \\
\hline cytosine & 0.024 & 0.018 & 0.017 & 0.025 & $\begin{array}{l}0.02 \\
\end{array}$ & 0.017 & 0.054 & 0.048 & 0.048 & 0.045 & $\begin{array}{l}0.04 \\
0.04\end{array}$ & 0.035 \\
\hline dihydrofolate & 0 & 0 & 0 & 0 & 0 & 0 & 0 & 0 & 0 & 0 & 0 & \\
\hline dihydroorotate & 0.002 & 0.002 & 0 & 0 & 0.002 & 0 & 0.089 & 0.072 & 0.057 & 0.079 & 0.061 & 0.055 \\
\hline etone_phosphate & 0 & 0 & 0 & 0 & 0 & 0 & 0.019 & 0.014 & 0.019 & 0.025 & 0.029 & 0.029 \\
\hline dTMP & 0.009 & 0.012 & 0.012 & 0.011 & 0.014 & 0.014 & 0.042 & 0.046 & 0.048 & 0.057 & 0.046 & 0.041 \\
\hline dTTP & 0 & 0 & 0 & 0 & 0 & 0 & 0 & 0 & 0 & 0 & 0 & 0 \\
\hline dUMP & 0 & 0 & 0 & 0 & 0 & 0 & 0 & 0 & 0 & 0 & 0 & 0 \\
\hline rose_4-phosphate & 0 & 0 & 0 & 0 & 0 & 0 & 0 & 0 & 0 & 0 & 0 & \\
\hline F6P/G1P & 0.287 & 0.356 & 0.348 & 0.282 & 0.358 & 0.345 & 0.373 & 0.361 & 0.396 & 0.459 & 0.432 & 0.457 \\
\hline FAD & 0 & 0 & 0 & 0 & 0 & 0 & 0 & 0 & 0 & 0 & 0 & 0 \\
\hline folate & 0 & 0 & 0 & 0 & 0 & 0 & 0 & 0 & 0 & 0 & 0 & 0 \\
\hline _1,6-bisphosphate & 0 & 0 & 0 & 0 & 0 & 0 & 0 & 0 & 0 & 0 & 0 & 0 \\
\hline fumarate & 0.296 & 0.327 & 0.265 & 0.271 & 0.309 & 0.392 & 0.225 & 0.201 & 0.278 & 0.252 & 0.288 & 0.193 \\
\hline GAR & 0 & 0 & 0 & 0 & 0 & 0 & 0 & 0 & 0 & 0 & 0 & 0 \\
\hline GDP & 0 & 0 & 0 & 0 & 0 & 0 & 0 & 0 & 0 & 0 & 0 & 0 \\
\hline glucose & 0.752 & 0.584 & 0.473 & 0.744 & 0.501 & 0.538 & 0.614 & 0.463 & 0.483 & 0.629 & 0.497 & 0.524 \\
\hline cose_6-phosphate & 0.222 & 0.206 & 0.218 & 0.22 & 0.234 & 0.216 & 0.671 & 0.608 & 0.667 & 0.813 & 0.816 & 0.819 \\
\hline glutamate & 84.184 & 84.682 & 85.275 & 72.85 & 73.625 & 73.377 & 117.586 & 112.611 & 114.603 & $\begin{array}{r}179.119 \\
179\end{array}$ & 166.407 & 174.768 \\
\hline tamate_13C5-15N & 0 & 0 & 0 & 0 & 0 & 0 & 0 & 0 & 0 & 0 & 0 & \\
\hline glutamine & 0.085 & 0.095 & 0.088 & 0.1 & 0.092 & 0.101 & 0.079 & 0.069 & 0.072 & 0.115 & 0.104 & 0.108 \\
\hline iyde_3-phosphate & 0 & 0 & 0 & 0 & 0 & 0 & 0.019 & 0.014 & 0.019 & 0.028 & 0.029 & 0.029 \\
\hline erol_3-phosphate & 0.287 & 0.361 & 0.389 & 0.365 & 0.473 & 0.482 & 0.23 & 0.254 & 0.296 & 0.226 & 0.257 & 0.273 \\
\hline rophosphocholine & 0.371 & 0.423 & 0.479 & 0.996 & 0.749 & 0.593 & 0.48 & 0.443 & 0.387 & 0.567 & 0.543 & 0.591 \\
\hline glycine & 0 & 3.749 & 1.043 & 0 & 0.686 & 0 & 0 & 0 & 0 & 0.306 & 0 & \\
\hline glycine_13C2-15N & 0 & 0 & 0 & 0 & 0 & 0 & 0 & 0 & 0 & 0 & 0 & \\
\hline GMP & 0.065 & 0.064 & 0.074 & 0.066 & 0.072 & 0.073 & 0.052 & 0.042 & 0.052 & 0.073 & 0.072 & 0.082 \\
\hline GSH & 1.067 & 0 & 0 & 1.539 & 0.472 & 0.401 & 0 & 0.378 & 0 & 0 & 0.476 & 0.461 \\
\hline GSSG & 0 & 0 & 0 & 0 & 0 & 0 & 0 & 0 & 0 & 0 & 0 & \\
\hline GTP & 0 & 0 & 0 & 0 & 0 & 0 & 0 & 0 & 0 & 0 & 0 & 0 \\
\hline
\end{tabular}


bioRxiv preprint doi: https://doi.org/10.1101/2022.01.07.475452; this version posted January 9, 2022. The copyright holder for this preprint (which was not certified by peer review) is the author/funder, who has granted bioRxiv a license to display the preprint in perpetuity. It is made available under aCC-BY-NC-ND 4.0 International license.

Table S2 continued

\begin{tabular}{|c|c|c|c|c|c|c|c|c|c|c|c|c|}
\hline guanidinoacetate & 0 & 0 & 0 & 0 & 0 & 0 & 0 & 0 & 0 & 0 & 0 & 0 \\
\hline guanine & 0 & 0 & 0 & 0 & 0 & 0 & 0 & 0 & 0 & 0 & 0 & 0 \\
\hline guanosine & 0.014 & 0.012 & 0.013 & 0.014 & 0.009 & 0.003 & 0.013 & 0.008 & 0.008 & 0.194 & 0.231 & 0.244 \\
\hline histidine & 0.108 & 0.158 & 0.186 & 0.148 & 0.177 & 0.135 & 0.145 & 0.053 & 0 & 0.027 & 0.037 & 0.017 \\
\hline :tidine_13C6-15N3 & 0 & 0 & 0 & 0 & 0 & 0 & 0 & 0 & 0 & 0 & 0 & 0 \\
\hline homocysteine & 0 & 0 & 0 & 0 & 0 & 0 & 0 & 0 & 0 & 0 & 0 & 0 \\
\hline hydroxyproline & 0.002 & 0.002 & 0.002 & 0.003 & 0.002 & 0.002 & 0.001 & 0.001 & 0.001 & 0.001 & 0 & 0.001 \\
\hline hypotaurine & 0 & 0 & 0 & 0 & 0 & 0 & 0 & 0 & 0 & 0 & 0 & 0 \\
\hline hypoxanthine & 0.506 & 0.446 & 0.393 & 0.548 & 0.444 & 0.445 & 0.26 & 0.244 & 0.225 & 0.282 & 0.256 & 0.233 \\
\hline & 0 & 0 & 0 & 0 & 0 & 0 & 0.074 & 0.073 & 0.08 & 0.074 & 0.06 & 0.055 \\
\hline inosine & 0 & 0 & 0 & 0 & 0 & 0 & 0 & 0 & 0 & 0 & 0 & 0 \\
\hline isoleucine & 0.144 & 0.078 & 0.179 & 0.104 & 0.142 & 0.125 & 0.147 & 0.089 & 0.074 & 0.241 & 0.115 & 0.212 \\
\hline leucine_13C6-15N & 0 & 0 & 0 & 0 & 0 & 0 & 0 & 0 & 0 & 0 & 0 & 0 \\
\hline itaconic_acid & 0.517 & 0.523 & 0.563 & 0.512 & 0.549 & 0.555 & 0.484 & 0.409 & 0.427 & 0.477 & 0.4 & 0.429 \\
\hline kynurenic_acid & 0 & 0 & 0 & 0 & 0.002 & 0 & 0.15 & 0.009 & 0 & 0 & 0 & 0 \\
\hline kynurenine & 0 & 0 & 0 & 0 & 0 & 0 & 0 & 0 & 0 & 0 & 0 & 0 \\
\hline lactate & 82.724 & 76.936 & 79.031 & 90.337 & 74.404 & 68.273 & 7.91 & 6.312 & 5.866 & 9.111 & 7.767 & 7.769 \\
\hline leucine & 0.129 & 0.154 & 0.195 & 0.17 & 0.134 & 0.147 & 0.173 & 0.126 & 0.072 & 0.178 & 0.195 & 0.078 \\
\hline leucine_13C6-15N & 0 & 0 & 0 & 0 & 0 & 0 & 0 & 0 & 0 & 0 & 0 & 0 \\
\hline lysine & 1.038 & 1.112 & 1.052 & 1.105 & 1.168 & 1.119 & 0.129 & 0.088 & 0.064 & 0.188 & 0.196 & 0.166 \\
\hline lysine_13C6-15N2 & 0 & 0 & 0 & 0 & 0 & 0 & 0 & 0 & 0 & 0 & 0 & 0 \\
\hline malate & 0.626 & 0.526 & 0.413 & 0.608 & 0.509 & 0.473 & 0.315 & 0.179 & 0.159 & 0.191 & 0.21 & 0.212 \\
\hline methionine & 0 & 0 & 0 & 0 & 0 & 0 & 0 & 0 & 0 & 0 & 0 & 0 \\
\hline hionine_13C6-15N & 0 & 0 & 0 & 0 & 0 & 0 & 0 & 0 & 0 & 0 & 0 & 0 \\
\hline thylthioadenosine & 0.027 & 0.025 & 0.024 & 0.032 & 0.032 & 0.028 & 0 & 0 & 0.001 & 0.005 & 0.003 & 0.003 \\
\hline a_acetylglutamine & 0 & 0 & 0 & 0 & 0 & 0 & 0.637 & 0.648 & 0.688 & 0.628 & 0.677 & 0.505 \\
\hline Na-acetylornithine & 0.108 & 0.145 & 0.164 & 0.128 & 0.157 & 0.18 & 0.546 & 0.585 & 0.666 & 0.632 & 0.717 & 0.687 \\
\hline $\mathrm{N}$-acetylcysteine & 0 & 0 & 0 & 0 & 0 & 0 & 0 & 0 & 0 & 0 & 0 & 0 \\
\hline N-acetylglutamate & 0.064 & 0.087 & 0.086 & 0.066 & 0.09 & 0.088 & 0.307 & 0.269 & 0.314 & 0.316 & 0.307 & 0.364 \\
\hline -acetylmethionine & 0 & 0 & 0 & 0 & 0 & 0 & 0 & 0 & 0 & 0 & 0 & 0 \\
\hline etylphenylalanine & 0 & 0 & 0 & 0.001 & 0 & 0 & 0.007 & 0.006 & 0.005 & 0.007 & 0.008 & 0.005 \\
\hline NAD & 0.009 & 0.01 & 0.003 & 0.009 & 0.01 & 0.011 & 0.017 & 0.014 & 0.009 & 0.038 & 0.038 & 0.043 \\
\hline $\mathrm{NADH}$ & 0 & 0 & 0 & 0 & 0 & 0 & 0 & 0 & 0 & 0 & 0 & 0 \\
\hline NADP & 0 & 0 & 0 & 0 & 0 & 0 & 0 & 0 & 0 & 0 & 0 & 0 \\
\hline NADPH & 0 & 0 & 0 & 0 & 0 & 0 & 0 & 0 & 0 & 0 & 0 & 0 \\
\hline Ne-acetyllysine & 1.14 & 1.504 & 1.664 & 1.416 & 1.876 & 1.671 & 0.77 & 0.94 & 1.195 & 1.088 & 1.127 & 1.355 \\
\hline nicotinamide & 0.004 & 0.003 & 0.003 & 0.005 & 0.003 & 0.004 & 0.014 & 0.015 & 0.01 & 0.017 & 0.016 & 0.014 \\
\hline nicotinic_acid & 12.087 & 9.806 & 8.594 & 12.859 & 10.448 & 9.991 & 0.043 & 0.039 & 0.039 & 0.06 & 0.05 & 0.05 \\
\hline ornithine & 0 & 0 & 0.045 & 0 & 0.02 & 0 & 0.036 & 0 & 0 & 0 & 0.025 & 0 \\
\hline orotate & 0.002 & 0.003 & 0 & 0.005 & 0.001 & 0 & 0.134 & 0.125 & 0.095 & 0.138 & 0.125 & 0.079 \\
\hline palmitate & 2.992 & 1.47 & 1.064 & 10.07 & 3.147 & 2.84 & 0.091 & 0.028 & 0.024 & 0.027 & 0.024 & 0.109 \\
\hline pantothenic_acid & 0.346 & 0.339 & 0.424 & 0.367 & 0.368 & 0.362 & 1.858 & 1.928 & 2.157 & 1.741 & 1.657 & 1.73 \\
\hline lacetyl_glutamine & 0 & 0 & 0 & 0 & 0 & 0 & 0 & 0 & 0 & 0 & 0 & 0 \\
\hline phenylalanine & 1.621 & 1.522 & 1.481 & 1.775 & 1.651 & 1.572 & 0.181 & 0.142 & 0.133 & 0.201 & 0.186 & 0.182 \\
\hline talanine-13C9-15N & 0 & 0 & 0 & 0 & 0 & 0 & 0 & 0 & 0 & 0 & 0 & 0 \\
\hline phosphocholine & 0.583 & 0.626 & 0.708 & 0.767 & 0.857 & 0.741 & 0.026 & 0.015 & 0.007 & 0.044 & 0.021 & 0.048 \\
\hline phosphocreatine & 0 & 0 & 0 & 0 & 0 & 0 & 0 & 0 & 0 & 0 & 0 & 0 \\
\hline sphoenolpyruvate & 0.004 & 0.005 & 0.005 & 0.007 & 0.005 & 0.008 & 0.11 & 0.121 & 0.136 & 0.15 & 0.147 & 0.15 \\
\hline phoethanolamine & 0.094 & 0.079 & 0.085 & 0.097 & 0.117 & 0.112 & 0 & 0 & 0 & 0 & 0 & 0 \\
\hline phosphoserine & 0 & 0 & 0 & 0 & 0 & 0 & 0 & 0 & 0 & 0 & 0 & 0 \\
\hline pipecolic_acid & 0.001 & 0 & 0 & 0.001 & 0.002 & 0.001 & 0.001 & 0 & 0.002 & 0.002 & 0.001 & 0.001 \\
\hline proline & 1.117 & 1.104 & 1.127 & 1.254 & 1.229 & 1.217 & 0.098 & 0.048 & 0.037 & 0.042 & 0.051 & 0.045 \\
\hline proline_13C5-15N & 0 & 0 & 0 & 0 & 0 & 0 & 0 & 0 & 0 & 0 & 0 & 0 \\
\hline propionylcarnitine & 0 & 0 & 0 & 0 & 0 & 0 & 0 & 0 & 0 & 0 & 0 & 0 \\
\hline PRPP & 0 & 0 & 0 & 0 & 0 & 0 & 0 & 0 & 0 & 0 & 0 & 0 \\
\hline pseudouridine & 0.001 & 0.001 & 0 & 0.001 & 0.001 & 0.001 & 0 & 0 & 0 & 0.001 & 0 & 0 \\
\hline pyruvate & 0.313 & 0.274 & 0.277 & 0.337 & 0.284 & 0.254 & 0.019 & 0 & 0 & 0.019 & 0 & 0 \\
\hline lose_5-phosphate & 0.004 & 0.008 & 0.011 & 0.014 & 0.021 & 0.022 & 0.068 & 0.074 & 0.08 & 0.085 & 0.105 & 0.093 \\
\hline oose_1-phosphate & 0.082 & 0.078 & 0.085 & 0.083 & 0.098 & 0.086 & 0.104 & 0.076 & 0.088 & 0.119 & 0.111 & 0.137 \\
\hline saccharopine & 0 & 0 & 0 & 0 & 0 & 0 & 0 & 0 & 0 & 0 & 0 & 0 \\
\hline osylhomocysteine & 0 & 0 & 0 & 0 & 0 & 0 & 0 & 1.51 & 0 & 0 & 0 & 0 \\
\hline enosylmethionine & 5.047 & 0 & 0 & 5.538 & 3.85 & 3.792 & 0 & 5.398 & 0 & 0 & 6.587 & 6.113 \\
\hline sarcosine & 0 & 0 & 0 & 0 & 0 & 0 & 0 & 0 & 0 & 0 & 0 & 0 \\
\hline lose_7-phosphate & 0.016 & 0.017 & 0.015 & 0.022 & 0.019 & 0.017 & 0.151 & 0.128 & 0.145 & 0.139 & 0.121 & 0.15 \\
\hline serine & 0.115 & 0.226 & 0.855 & 0.27 & 0.225 & 0.166 & 1.121 & 0.214 & 0 & 0.082 & 0.271 & 0.145 \\
\hline serine_13C3-15N & 0 & 0 & 0 & 0 & 0 & 0 & 0 & 0 & 0 & 0 & 0 & 0 \\
\hline S-methylcysteine & 0 & 0 & 0 & 0 & 0 & 0 & 0 & 0 & 0 & 0 & 0 & 0 \\
\hline succinate & 0.188 & 0.205 & 0.19 & 0.179 & 0.194 & 0.192 & 0.16 & 0.202 & 0.194 & 0.355 & 0.291 & 0.287 \\
\hline taurine & 0.276 & 0 & 0 & 1.067 & 0.563 & 0.331 & 0 & 14.037 & 0 & 0 & 15.047 & 11.682 \\
\hline threonine & 0.293 & 0.32 & 0.435 & 0.386 & 0.372 & 0.334 & 0.38 & 0.249 & 0.129 & 0.194 & 0.246 & 0.24 \\
\hline reonine_13C4-15N & 0 & 0 & 0 & 0 & 0 & 0 & 0 & 0 & 0 & 0 & 0 & 0 \\
\hline tryptophan & 0 & 0 & 0 & 0 & 0 & 0 & 0 & 0 & 0 & 0 & 0 & 0 \\
\hline tyrosine & 0.479 & 0.525 & 0.585 & 0.584 & 0.58 & 0.573 & 0.2 & 0.156 & 0.154 & 0.19 & 0.188 & 0.212 \\
\hline yrosine_13c9-15N & 0 & 0 & 0 & 0 & 0 & 0 & 0 & 0 & 0 & 0 & 0 & 0 \\
\hline UDP & 0 & 0 & 0 & 0 & 0 & 0 & 0 & 0 & 0 & 0 & 0 & 0 \\
\hline UDP-GICNAC & 0 & 0 & 0 & 0 & 0 & 0 & 0 & 0 & 0 & 0 & 0 & 0 \\
\hline UDP-hexose & 0 & 0 & 0 & 0 & 0 & 0 & 0.013 & 0.015 & 0.012 & 0.034 & 0.028 & 0.029 \\
\hline UMP & 0.089 & 0.091 & 0.09 & 0.095 & 0.093 & 0.085 & 0.154 & 0.134 & 0.154 & 0.144 & 0.142 & 0.146 \\
\hline uracil & 0.08 & 0.058 & 0.043 & 0.079 & 0.054 & 0.053 & 0.016 & 0.014 & 0.011 & 0.022 & 0.018 & 0.008 \\
\hline urate & 0.042 & 0.091 & 0.028 & 0.048 & 0.035 & 0.031 & 0.272 & 0.158 & 0.167 & 0.459 & 0.374 & 0.374 \\
\hline uridine & 0.012 & 0.006 & 0.006 & 0.012 & 0.009 & 0.007 & 0.006 & 0.005 & 0.006 & 0.006 & 0.007 & 0.005 \\
\hline UTP & 0 & 0 & 0 & 0 & 0 & 0 & 0 & 0 & 0 & 0 & 0 & 0 \\
\hline valine & 0.464 & 0.443 & 0.386 & 0.538 & 0.464 & 0.457 & 0.374 & 0.423 & 0.332 & 0.36 & 0.336 & 0.446 \\
\hline valine-13C5-15N & 0 & 0 & 0 & 0 & 0 & 0 & 0 & 0 & 0 & 0 & 0 & 0 \\
\hline xanthine & 0.321 & 0.27 & 0.2 & 0.369 & 0.252 & 0.252 & 0.107 & 0.079 & 0.074 & 0.089 & 0.09 & 0.077 \\
\hline xanthosine & 0 & 0 & 0 & 0 & 0 & 0 & 0 & 0 & 0 & 0 & 0 & \\
\hline
\end{tabular}




\section{Movie S1. Timelapse microscopy of N-QTF incorporation in M. smegmatis}

Representative timelapse microscopy experiment of N-QTF incorporation into growing M. smegmatis mc2155 under constant flow of 7H9 medium and N-QTF. Images were acquired every 15 minutes. Images representative of this movie were compiled into Figure 2A.

Movie S2. Timelapse microscopy of N-QTF incorporation in M. smegmatis exposed to EMB Representative timelapse microscopy experiment of N-QTF incorporation into growing M. smegmatis mc2155 under constant flow of $7 \mathrm{H} 9$ medium, N-QTF and then ethambutol treatment. Images were acquired every 15 minutes. Images representative of this movie were compiled into Figure $2 \mathrm{~B}$.

Movie S3. Timelapse microscopy of N-QTF incorporation in M. smegmatis exposed to INH Representative timelapse microscopy experiment of N-QTF incorporation into growing M. smegmatis mc2155 under constant flow of 7H9 medium, N-QTF and then isoniazid treatment. Images were acquired every 15 minutes. Images representative of this movie were compiled into Figure $2 \mathrm{C}$.

Movie S4. Timelapse microscopy of N-QTF incorporation in M. smegmatis exposed to RIF Representative timelapse microscopy experiment of N-QTF incorporation into growing M. smegmatis mc2155 under constant flow of 7H9 medium, N-QTF and then rifampicin treatment. Images were acquired every 15 minutes. Images representative of this movie were compiled into Figure 2D. 